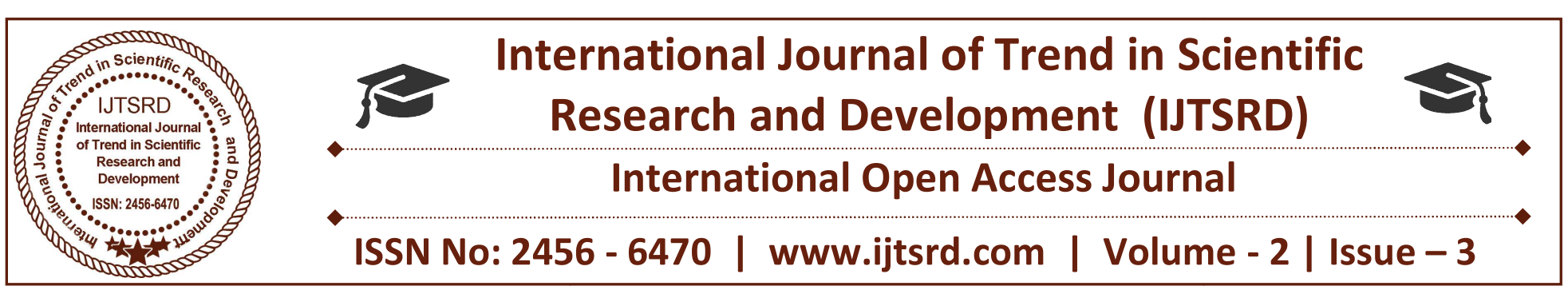

\title{
Lignin Degradation: A Review
}

\section{U. Priyanga}

PG and Research Department of Microbiology, STET Women's college, Sundarakkottai, Mannargudi, Thiruvarur, Tamil Nadu, India

\author{
M. Kannahi \\ PG and Research Department of Microbiology, \\ STET Women's college, Sundarakkottai, \\ Mannargudi, Thiruvarur, Tamil Nadu, India
}

\begin{abstract}
Lignin is regarded as the most plentiful aromatic polymer contains both non-phenolic and phenolic structures. It makes the integral part of secondary wall and plays a significant role in water conduction in vascular plants. Many fungi, bacteria and insects have ability to decrease this lignin by producing enzymes. Certain enzymes from specialized bacteria and fungi have been identified by researchers that can metabolize lignin and enable utilization of lignin -derived carbon sources. In this review, we attempt to provide an overview of the complexity of lignin's polymeric structure, its distribution in forest soils, and its chemical nature. Herein, we focus on lignin biodegradation by various microorganism, fungi and bacteria present in plant biomass and soils that are capable of producing ligninolytic enzymes such as lignin peroxidase, manganese peroxidase, versatile peroxidase, and dye - decolorizing peroxidase. The relevant and recent reports have been included in this review.
\end{abstract}

Keywords: Fungi, bacteria, ligninolytic enzymes, lignin peroxidase, manganese peroxidase, versatile peroxidase, dye- decolorizing peroxidase, degradation

\section{INTRODUCTION}

Lignin is the most common aromatic organic compound found in the lignocellulose component of the plant cell wall. Its characteristic ability to absorb UV (ultraviolet) radiation makes it susceptible to degradation. on being exposed to sunlight. The source of lignin in soil can be of plant origin or lignocellulosic waste from the food processing industry. It represents a significant part of plant litter input (approximately 20\%) into the soil. Lignin is an amorphic three-dimensional polymer composed of phenylpropanoid subunits. It acts as a binding material and is involved in cross-linking of cellulose that provides extra strength, rigidity, and stiffness to the cell wall. Lignin protects plant cells from enzymatic tif hydrolysis and various other environmental stress conditions. The complex structure of lignin makes it recalcitrant to most degradation methods and continues to pose a critical challenge.

Lignin is the most abundant source of carbon in the soil after cellulose. Lignin degradation can thus play a major role in improving earth's biofuel resources and also serve as an alternative to harsh technologies used in the paper and pulp industry. Degradation studies are mainly biotic, aerobic, and co-metabolic. Studies have shown that certain bacteria and fungi are able to break down various biopolymers in soil. Lignocellulosic biomass degradation has been widely studied in wood-rotting Baciomycetes fungi due to their potential to degrade lignin.

In this review, we discuss the structural diversity of the lignin molecule, its distribution in soil, and also biodegradation of lignin by various groups of fungi and bacteria by reviewing the pertinent literature. 


\section{Lignocellulose}

On the world lignocelluloses are the main part of biomass, because it is a renewable resource and the prominent structural component of plant cell wall as well. Lignocellulosic wastes are released in large amounts by many industries. Plant cell wall is generally composed of cellulose (35\% to $50 \%$ ), hemicellulose $(20 \%$ to $35 \%)$, and lignin $(15 \%$ to $20 \%$ ). Cellulose is the dominant part of lignocellulose and consist of a linear chain of Dglucose linked by $\beta$ (1-4)-glycosidic bonds to each other. The cellulose strains are connected to each other deliver cellulose fibril. A number of intra- and intermolecular hydrogen bonds are linked cellulose fibers together. Hemicellulose is the second plentiful constituent of lignocellulose, is comprised of diverse pentoses (arabinose, xylose) and hexoses (mannose, galactose, glucose). So, that large amount of hemicelluloses must be eliminated to improve the cellulose digestibility for the enzymatic hydrolysis. Lignin primarily is consisted of $p$-coumaryl phenol (H), guaiacyl (G) and sinapyl //alcohol (S). Polymerization of these constituents mainly synthesize lignin and their proportion is different between crops, woody plants and also in the primary and secondary cell wall.

\section{Lignin Structure and Its Biosynthesis}

In the plant cell, lignin is biosynthesized by the combination of three basic hydroxycinnamoyl alcohol. In the monomers plant cell, or monolignols: ligninisbiosynthesized by the combination of three basic hydroxycinnamoyl alcohol monomers or monolignols:

1. p-Coumaryl alcohol;

2. Coniferyl alcohol;

3. Sinapyl alcohol.

These monolignols are often referred to as phenylpropanoids, which differ in the substitutions at the 3-C and 5-C positions in the aromatic ring.

Lignin synthesis starts with the random selfreplicating radical coupling of phenoxy radical to form an oligomeric product. After polymerization, these polymers are referred as $p$-hydroxyphenyl
$(\mathrm{H})$, guaiacyl (G), and syringyl (S) (from $p$-coumaryl alcohol, coniferyl alcohol, and sinapyl alcohol,

respectively). Monolignols are linked either by $\mathrm{C}-\mathrm{C}$ bond or $\mathrm{C}-\mathrm{O}-\mathrm{C}$ bond, and more than two third of monolignols are joined by either linkages.

\section{Lignin in Soil}

Because of the high inflow of organic aromatic matter into the soil, lignin is considered a major component of soil organic matter. The High stability and low degradability of lignin soil contribute to increasing humus formation. The copper oxidation $(\mathrm{CuO})$ method is commonly used for the characterization and quantification of lignin in soil. Oxidation by $\mathrm{CuO}$ yields phenolic compounds such as vanillyl, syringyl, and cinnamyl type compounds. These compounds reflect the origin and extent of lignin decomposition in the soil. The sum of the above three monomeric phenolic components gives an estimate of total lignin in the soil, whereas the carboxylic acid to aldehyde ratio conveys the extent of lignin decomposition. Studies have shown that biotic, aerobic, and co-metabolic degradation are the main processes involved in lignin degradation.

\section{Lignin Distribution in Different Soil Horizons}

Distribution of lignin in different soil limits has been discussed by many groups. The lignin content in the soil decreases from the upper soil horizon to the lower soil horizon. However, in a few cases, an increase in lignin content of soil organic matter (SOM) with depth has been observed. Lignin distribution in soil could also vary with location.

A relatively higher rate of lignin degradation is found in lower horizon of soil as compared to the upper horizon because the acid-to-aldehyde ratios of the vanillyl and syringyl units are greater in lower horizon. An increase in gradient is found from organic to mineral horizon. This is in accordance with the decreasing vanillyl, syringyl, and cinnamyl phenolic-lignin contents with the depth and limited supply of fresh organic materials in deep soil horizons.

The particle size of soil components also influences the lignin content and acid-to-aldehyde ratio. The lignin content of SOM decreases from the coarse to the finest particle-size fractions while the acid-to- 
aldehyde ratio increases with decreasing particle size and is the highest in the clay fraction.

\section{Lignin Degradation in Soil}

The Lignocellulosic complex in the plant cell wall contains approximately 40 to $60 \%$ cellulose, 20 to $40 \%$ hemicellulose, and 10 to $25 \%$ lignin, which provides rigidity to the cell wall structure. Certain enzymes from specialized bacteria and fungi have been identified by researchers that can catalyze a number of oxidative and hydroxylation reactions, depolymerize the phenolic and non-phenolic lignin polymer, and also mineralize the insoluble lignin. The orientation, adsorption, and diffusion of the ligninolytic enzymes in the soil solid phase affect the lignin degradation in soil. In laboratory studies, the impact of soil particle size on soil respiration was observed by Datta et al., which can, in turn, affect lignin degradability in soil.

The biodegradation of lignocellulosic biomass has been widely studied in wood rotting Baciomyecetes microorganisms. These baciomyecetes are categorized as white-rot and brown-rot fungi. Whiterot fungi are the most effective bio-degraders of lignocellulosic biomass (e.g., Phanerochaete chrysosporium) and can degrade lignin faster than other microorganisms. Su et al. reported that the degradation rate of lignin by Phanerochaete chrysosporium in tobacco stalk was $53.75 \%$ in 15 days.

White-rot fungi produce a number of extracellular enzymes that directly attack lignin, cellulose, and hemicellulose of the plant cell wall to decompose it. These enzymes include laccases and peroxidases, such as lignin peroxidase (LiP), manganese peroxidase (MnP), and versatile peroxidase (VP). Laccases and peroxidase enzymes can also cause lignin degradation through low molecular weight free radicals such a $\mathrm{OH}$, depolymerize the phenolic and non-phenolic lignin polymer, and mineralize the insoluble lignin.

On the other hand, the brown-rot fungi are less efficient in degrading lignin compared to white-rot fungi. Lignin degradation by brown- rot fungi mainly involves non-enzymatic oxidation reactions producing hydroxyl radicals via Fenton chemistry.
Brown-rot fungi partially oxidize lignin via aromatic ring demethylation. During this process, the phenolic hydroxyl content of the reaction mixture increases due to partial oxidation and partially due to the addition of new carboxyl and carbonyl groups.

Research in terms of lignin degradation by bacteria has been limited. Although fungi are reported to be more potent in lignin degradation, many soil bacteria such as Actinomycetes are also capable of mineralizing and solubilizing polymeric lignin and lignin-related compounds. Spiker showed that bacteria (e.g., Streptomyces. viridosporus) could oxidize phenolics but not the non- phenolic compounds. Various types of cleavages in lignin molecules, e.g., aromatic ring, demethylation, and oxidation, are catalyzed by bacterial enzymes.

Lignin-degrading fungi and bacteria can produce primarily four major extracellular heme peroxidases, including lignin peroxidase (LiP, EC 1.11.1.14), manganese-dependent peroxidase (MnP, EC1.11.1.13),versatile peroxidase (VP,EC EC1.11.1.16), and laccase (Lac, EC 1.10.3.2). Theses enzymes can directly attack lignin, cellulose, and hemicellulose of the plant cell wall to decompose it. Litter decomposing fungi of families such as strophariaceae, tricholomataceae, and bolbitiaceae have been found to have an evident expression of MnP. Recently, a new group of peroxidases has been identified in fungi and bacteria that is capable of degrading lignin, known as

dye-decolorizing peroxidases (DyPs, EC 1.11.1.19).

\section{Steps in Lignin Degradation}

Lignin biodegradation involves both depolymerization and aromatic ring cleavage. Extracellular

Enzyme brought about oxidation of lignin in the following steps:

1. Oxidation of $\beta-\mathrm{O}-4$ linkages to arylglycerol compounds;

2. Aromatic rings cleavage, mostly follows the $\beta$-ketoadipate pathway;

3. Cleaved aromatic rings coupled with $\beta-\mathrm{O}-4$ oxidation leads to the formation of cyclic carbonate structures. 
The lignin-protein and lignin theories hypothesize that during the formation of humic acid from lignin, lignin first breaks down into smaller constituents, and later, these small constituents recombine to form more complex organic molecules.

\section{Biodegradation of lignin}

\section{Humification}

Humification is a process of conversion of dead organic matter (leaves, twigs, etc.) into humus by the action of decomposers such as bacteria and fungi. Humification affects soil property and nature. Due to its complex nature, chemical composition, and structure, humus is still not well understood. Different theories have been proposed on humification but doubt still exists, and none of them are universally accepted. The heterogeneous nature of soil makes it difficult to generalize different experimental results. A study was done in 2009 by Alianiello et al. to investigate the different steps of humification and the changes that occur during humification. At the beginning of the experiment, a high degree of humification is seen in lignin treated soil. The overall result shows that all the natural substances tend to be almost completely mineralized or converted to substances similar to those of the treated soil, excluding lignin, which after a year incubation is still analytically recognizable in the soil.

\section{Lignin-degrading fungi}

Lignin degraders in nature are mainly white-rot fungi. There are several thousand species of whiterot fungi, most of them Basidiomycotina, in addition to a few Ascomycotina which can cause white-rot (Eriks-son et al., 1990). White-rot fungi belonging to the sub-division Basidiomycotina attack either hardwood or softwood, while Ascomycotina probably degrade only hardwood (Kirk and Farrell, 1987). Lignin degradation by white-rot fungi is faster than that of any other organisms and they are responsible for most of the lignin decomposition in nature. However, the growth substrate is not only lignin, but also hemicelluloses and cellulose (Buswell and Odier, 1987; Kirk and Farrell, 1987; Blanchette, 1995). The growth of fungi decreases in nitrogen- or carbon-depleted conditions and ligninolytic activity appears as a form of secondary metabolism (Brown, 1985; Kirk and Farrell, 1987).

White-rot fungi can cause selective or nonselective delignification of wood. In selective delignification, lignin is removed without any marked loss of cellulose, and in nonselective delignification all the major cell wall components are degraded (Eriksson et al., 1990; Blanchette, 1995). Although some white-rot fungi al-ways attack wood either in a selective or in nonselective way, there are fungi which are capable of both forms of degradation, e.g. Heterobasidion annosum (Eriksson et al., 1990; Blanchette, 1995). Among the best studied white-rot fungi are Phanerochaete chrysosporium and Phlebia radiata, which degrade lignin selectively, and Trametes versicolor which degrades lignin nonselectively (Hatakka, 1994).

White-rot fungi degrade lignin by means of oxidative enzymes (Hatakka, 1994). Because of the nature and size of the lignin molecule, the enzymes responsible for the initial attack must be extracellular and nonspecific (Kirk and Farrell, 1987; Hatakka, 1994). The best studied extracellular enzymes of white-rot fungi are lignin per-oxidases (LiPs), manganese peroxidases (MnPs) and laccase. The role of LiP and $\mathrm{MnP}$ in lignin degradation has been verified, while that of other enzymes is still uncertain (Hatakka, 1994). Di erent white-rot fungi produce di erent combinations of enzymes: there are fungi producing $\mathrm{LiP}$ and $\mathrm{MnP}$, fungi producing $\mathrm{MnP}$ and laccase, fungi producing $\mathrm{LiP}$ and laccase and fungi which produce neither LiP nor MnP, but laccase and aryl alcohol oxidase (AAO) or some other enzyme (Hatakka 1994). P. chrysosporium, P. radiata and T. versicolor belong to the $\mathrm{LiP} \pm \mathrm{MnP}$ group. Usually the members of this group also produce laccase, but $\mathrm{P}$. chrysosporium is an exception, although very recently laccase production by this fungus has been reported under specific conditions (Srinivasan et al., 1995). Several fungi belonging to the $\mathrm{LiP} \pm \mathrm{MnP}$ and the $\mathrm{MnP}$-laccase groups are e ective lignin degraders, while the lignin degradation capability of fungi belonging to the LiP-laccase group is much lower (Hatakka, 1994). This may be due to the essential role of $\mathrm{MnP}$ in lignin de-gradation. However, lignin degradation is a complex process and the enzymes have probably synergistic effects on each other. The mineralization of ${ }^{14} \mathrm{C}$-lignin in optimal conditions by 
the most effective white-rot fungi can reach $50 \%$ or even $70 \%$. In an experiment with several strains of $\mathrm{P}$. chrysosporium $\quad 45 \pm 50 \%$ of $\quad$ b- ${ }^{14} \mathrm{C}$-DHP was mineralized and $69 \%$ of the ${ }^{14} \mathrm{C}$-lignin from fir by one of the strains in 22 days (Hatakka et al., 1984).

Brown-rot fungi extensively degrade cellulose and hemicelluloses in wood, but lignin degradation is limit-ed. Lignin is chemically modified by demethylation of its phenolic and nonphenolic units (Kirk and Farrell, 1987; Eriksson et al., 1990), and limited aromatic hydroxylation and ring cleavage of lignin also occurs (Kirk and Farrell, 1987). Brownrot fungi are able to mineralize the methoxyl groups of lignin, but the mineralization of other parts is much lower (Buswell and Odier, 1987; Kirk and Farrell, 1987). Brown-rot fungi mainly colonize softwoods and only $6 \%$ of all wood-rotting Basidiomycotina are brownrotters (Rayner and Boddy, 1988). Brown-rotted wood is brown in colour, consisting of a high proportion of modified lignin residue and little carbohydrates, and it persists in the forest for a long time (Blanchette, 1995).

Soft-rot fungi are Ascomycotina or Deuteromycotina which degrade both hardwood and softwood, although hardwoods are degraded to a greater extent than soft-woods (Kuhad et al., 1997). All wood components are degraded, but the rate of degradation is minimal com-pared to that of white-rot or brownrot fungi (Eriksson et al., 1990). Soft-rot fungi degrade wood in environ-ments that are too severe for white- or brown-rot fungi, generally in wet environments (Blanchette, 1995). They also decompose plant litter in soils. Haider and Trojanowski (1980) and Rodriguez et al. (1996) studied the lignin mineralization capacity of soft-rot fungi. In 35 days, Chaetomium piluliferum mineralized $17 \%$ of ring- ${ }^{14} \mathrm{C}$-labelled corn stalk lignin, but the amount mineral-ized by other soft-rot fungi was much less (Haider and Trojanowski, 1980). Mineralization of side chain-and methoxy-labelled lignins by all fungi was slightly higher (Haider and Trojanowski, 1980). The soil fungi Peni-cillium chrysogenum, Fusarium solani and Fusarium oxysporum mineralized $20 \pm 27 \%$ of ${ }^{14} \mathrm{C}-\mathrm{MWL}$ from wheat straw in 28 days. $\mathrm{P}$. chrysogenum can also attack kraft and organosolv lignins (Rodriguez et al., 1996). Little is known about the enzyme system of soft-rot fungi or their lignin degradation capacity as litter de-composing organisms (Haider and Trojanowski, 1980; Kirk and Farrell, 1987). Lignin-related compounds, like vanillic acid and phenols, are rapidly degraded by soft-rot fungi (Haider and Trojanowski, 1980). This could mean that soft-rot fungi are an important group of lig-nin degraders in mixed populations, although their lignin degradation capacity alone is limited.

\section{Lignin-degrading bacteria}

There are many genera of actinomycetes and eubacteria which can degrade extracted lignin and DHP (Buswell and Odier, 1987). Many bacterial strains, especially actinomycetes, can solubilize and modify the lignin structure extensively, but their ability to miner-alize lignin is limited (Buswell and Odier, 1987; Ball et al., 1989; Eriksson et al., 1990; Godden et al., 1992). Actinomycetes degrade lignin as their primary metabolic activity and at high nitrogen levels compared to white-rot fungi, most of which degrade lignin via their secondary metabolism. Some species of Streptomyces and Nocardia have been shown to degrade some lignin in soil (Haider and Trojanowski, 1980). Streptomyces badius mineralizes $3.2 \%$ of ${ }^{14} \mathrm{C}$ MWL in 30 days, and mineralization was further enhanced to $11 \%$ when cel-lulose and yeast extract were added to the medium (Eriksson et al., 1990). There is some evidence that the grass lignins are attacked by actinomycetes more e-ciently than the wood lignins (Buswell and Odier, 1987).

The lignin-degrading eubacteria can be divided into erosion, cavitation and tunnelling bacteria (Eriksson et al., 1990; Blanchette, 1995). Wood is degraded by bacteria under certain extreme environmental conditions, e.g. wood saturated with water, almost anaerobic conditions or wood with a high extractive content. However, the rate of degradation is very slow (Eriksson et al., 1990; Blanchette, 1995). Erosion bacteria grow towards the middle lamella of the wood cells and cause erosion of the fibre wall, while tunnelling bacteria grow within the cell wall. The species of the tunnelling bac-teria have not been identified (Eriksson et al., 1990). Bacteria of several genera such as Pseudomonas, Al-caligenes, Arthrobacter, Nocardia and Streptomyces can degrade single-ring aromatic compounds. The role of bacteria may be significant in consuming the small molecular weight intermediate compounds produced by fungi (Vicuna, 1988; Ruttimann et al., 1991). 
Although aerobic microorganisms are primarily lignin degraders in most environments, it has been shown that anaerobic rumen microorganisms are cabable of degrading plant fibre cell walls (Kuhad et al., 1997). Colberg (1988) has reviewed the anaerobic microbial degradation of lignin compounds and concluded that the intermediate metabolic products called oligolignols, released during aerobic degradation, may be partially degraded to $\mathrm{CO}_{2}$ and $\mathrm{CH}_{4}$ by anaerobic microorgan-isms. Also, polymeric lignin is mineralized in anoxic sediments at a slow rate. In many studies, however, no anaerobic degradation of lignin has been observed (e.g. Hackett et al., 1977; Micales and Skog, 1997). Benner and Hodson (1985) reported that an elevated temperature of $55^{\circ} \mathrm{C}$ enhances the anaerobic degradation of lignin, nevertheless mineralization of DHP stays low. Chandler et al. (1980) have formulated an equation for the anaerobic degradation of di erent organic materials. Degradation is directly proportional to the lignin con-tent of the material:

$$
\mathrm{B}=0: 830-0: 028 \mathrm{X}
$$

where $\mathrm{B}$ is biodegradable fraction and $\mathrm{X}$ is the lignin content, $\%$ of the volatile solids. The data were collected from the anaerobic fermentation process using a wide range of lignocellulosic materials (Chandler et al., 1980).

Bacteria are typically unicellular with a size ranging from 0.5 to $3.0 \mathrm{~lm}$. Because of their small size bacteria have a very high surface/volume ratio, which allows rapid transfer of soluble substrates into the cell. As a result, bacteria are usually far more dominant than larger microorganisms such as fungi. Some bacteria, e.g. Bacillus spp., are capable of producing thick-walled endospores which are very resistant to heat, radiation and chemical disinfection (Haug, 1993).

A wide range of bacteria have been isolated from di erent compost environments, including species of Pseudomonas, Klebsiella and Bacillus (Nakasaki et al., 1985; Strom, 1985a,b; Falcon et al., 1987). Typical bacteria of the thermophilic phase are species of Bacil-lus, e.g. B. subtilis, B. licheniformis and $B$. circulans. Strom (1985b) reports that as much as $87 \%$ of the randomly selected colonies during the thermophilic phase of composting belong to the genus Bacillus. Many thermophilic species of Thermus have been isolated from compost at temperatures as high as $65^{\circ} \mathrm{C}$ and even $82^{\circ} \mathrm{C}(\mathrm{Be}$ a et al., 1996).

Actinomycetes are bacteria which form multicellular filaments, thus they resemble fungi. They appear during the thermophilic phase as well as the cooling and mat-uration phase of composting, and can occasionally be-come so numerous that they are visible on the surface of the compost. Thermophilic actinomycetes have been isolated from a wide range of natural substrates, e.g. from desert sand and compost (Cross, 1968). The genera of the thermophilic actinomycetes isolated from com-post include Nocardia, Streptomyces, Thermoactinomyces and Micromonospora (Waksman et al., 1939b; Strom, 1985a). Actinomycetes are able to degrade some cellulose, and solubilize lignin, and they tolerate higher temperatures and $\mathrm{pH}$ than fungi. Thus, actinomycetes are important agents of lignocellulose degradation dur-ing peak heating, although their ability to degrade cel-lulose and lignin is not as high as that of fungi (Crawford, 1983; Godden et al., 1992). Under adverse conditions actinomycetes survive as spores (Cross, 1968).

\section{Factors affecting fungal growth}

Temperature is one of the most important factors affecting fungal growth. Other important factors are sources of carbon and nitrogen, and the $\mathrm{pH}$. A moderately high level of nitrogen is needed for fungal growth although some fungi, mainly woodrotting fungi, grow at low nitrogen levels. Indeed, a low nutrient nitrogen level is often a prerequisite for lignin degradation (Eriksson et al., 1990; Dix and Webster, 1995). How-ever, low nutrient nitrogen is a rate-limiting factor for the degradation of cellulose (Dix and Webster, 1995). Most fungi prefer an acidic environment but tolerate a wide range of $\mathrm{pH}$, with the exception of the Basidiomycotina which do not grow well above pH 7.5. Coprinus species are the only Basidiomycotina which prefer an alkaline environment (Dix and Webster, 1995).

The majority of fungi are mesophiles which grow between $5^{\circ} \mathrm{C}$ and $37^{\circ} \mathrm{C}$, with an optimum temperature of $25 \pm 30^{\circ} \mathrm{C}$ (Dix and Webster, 1995). 
However, in the compost environment the elevated temperature means that the small group of thermophilic fungi is an important biodegradation agent. In nature, thermophilic fungi grow in garden compost heaps, bird nests, coal tips, power plant cooling pipes and e,uents, in the storage of many agricultural products (like hay, grain etc.) and in piles of wood chips and peat (Sharma, 1989; Dix and Webster, 1995). In mushroom compost, thermophilic fungi are responsible for the degradation of lignocellulose, which is a prerequisite for the growth of the edible fungus (Sharma, 1989).

Cooney and Emerson (1964) define thermophilic fungi as fungi with a maximum growth temperature of $50^{\circ} \mathrm{C}$ or higher and a minimum growth temperature of $20^{\circ} \mathrm{C}$ or higher. Thermotolerant species have a maxi-mum growth temperature of about $50^{\circ} \mathrm{C}$ and a mini-mum well below $20^{\circ} \mathrm{C}$ (Cooney and Emerson, 1964). Crisan (1973), however, defines thermophilic fungi as fungi with a temperature optimum of $40^{\circ} \mathrm{C}$ or higher. Thermophilic and thermotolerant fungi which are known to have cellulolytic or ligninolytic activity, or which have been found growing in lignocellulose sub-strate or compost.

Cooney and Emerson (1964), Crisan (1973), Rosenberg (1975), Brock (1978) and Mouchacca (1997) have enumerated several species and varieties of thermophilic fungi. The growth temperature optimum for most thermophilic fungi is between $40^{\circ} \mathrm{C}$ and $50^{\circ} \mathrm{C}$ and the maximum is $55^{\circ} \mathrm{C}$ (See Table 2). According to Cooney and Emerson (1964), $60^{\circ} \mathrm{C}$ is the temperature limit of fungi and, according to Brock (1978), $60 \pm 61.5^{\circ} \mathrm{C}$ is the temperature limit for all eukaryotes. Temperature tol-erance varies within the genera and even between the isolates of fungal species. The substrate may also have some in ${ }^{-}$uence on the temperature tolerance (Ofosu-Asiedu and Smith, 1973). There are indeed some reports of fungal growth above $61.5^{\circ} \mathrm{C}$. El-Naghy et al. (1991) reported saccharification activity of Sporotrichum ther-mophile (syn. Myceliophthora thermophile) at $65^{\circ} \mathrm{C}$, and Ofosu-Asiedu and Smith (1973) found Talaromyces emersonii still to be very active after four weeks at $60^{\circ} \mathrm{C}$ indicating that the fungus might be active at even higher temperatures. However, the growth of the fungus near the temperature maximum is very slow compared to that at the optimum temperature (Rosenberg, 1975).

The ligninolytic capacity of all thermophilic fungi is not known. However, most of them are known to be able to degrade wood or other lignocellulose, cellulose or hemicelluloses (e.g. Fergus, 1969; Ofosu-Asiedu and Smith, 1973; Sharma, 1989; Kuhad et al., 1997). The ability of fungi to hydrolyse hemicelluloses is probably more common than cellulose hydrolyzation (Dix and Webster, 1995).

The most e ective lignin degraders are Basidiomycotina, but according to Cooney and Emerson (1964) and Mouchacca (1997) all Basidiomycotina are mesophilic. However, a few Basidiomycotina grow well at elevated temperatures. Phanerochaete chrysosporium (anamorph Sporotrichum pulverulentum) is a white-rot fungus with an optimum temperature of $36 \pm 40^{\circ} \mathrm{C}$ and maximum temperature $46 \pm 49^{\circ} \mathrm{C}$ (Mouchacca, 1997). Ganoderma colossum is another white-rot fungus which is still capable of growing at $45^{\circ} \mathrm{C}$ and has an optimum temperature of $40^{\circ} \mathrm{C}$ (Adaskaveg et al., $1990 ; 1995)$. In the genus Coprinus there are some species that have an optimum temperature of above $40^{\circ} \mathrm{C}$ (Crisan, 1973). Some of the wood-rotting Coprinus species are brown-rot fungi which modify rather than degrade lignin (Rayner and Boddy, 1988).

A $=$ thermophilic Ascomycotina, Thermoascus aurantiacus, has a high ligninolytic capacity (Machuca et al., 1995), and it has been isolated from compost (von Klopotek, 1962). Heat-tolerant soft-rot fungi, such as Thielavia terrestris, Paecilomyces sp. and Talaromyces thermophilus, are weakly ligninolytic (Dix and Webster, 1995).

Nusbaumer et al. (1996), Thambirajah and Kuthubutheen (1989), Thambirajah et al. (1995), von Klo-potek (1962) and Waksman et al. (1939a,b) have studied the occurrence of fungi during composting. Waksman et al. (1939a,b) studied composting on a laboratory scale at temperatures of $28^{\circ} \mathrm{C}, 50^{\circ} \mathrm{C}, 65^{\circ} \mathrm{C}$ and $75^{\circ} \mathrm{C}$. At $28^{\circ} \mathrm{C}$ the population was heterogeneous with bacteria being dominant throughout the whole period, and fungi ap-pearing later. Fungi, together with bacteria and actino-mycetes, formed the microbial population in the compost at $50^{\circ} \mathrm{C}$. At the beginning there were active thermophilic fungi, 
which were followed by bacteria and actinomycetes, some of them growing on the fungal mycelium. The composts used in the other studies mentioned above were full scale.

The raw material of compost contains about $10^{6} \mathrm{mi}-$ crobial counts of mesophilic fungi/g of raw material and thermophilic fungi $10^{3} \pm 10^{6} / \mathrm{g}$ (von Klopotek, 1962; Thambirajah and Kuthubutheen, 1989; Thambirajah et al., 1995). The predominant mesophilic fungus in the raw material has been Geotrichum sp. (von Klopotek, 1962; Nusbaumer et al., 1996) and the thermotolerant fungus Aspergillus fumigatus (von Klopotek, 1962). Counts of fungi decrease as the temperature rises, and at $64^{\circ} \mathrm{C}$ all the thermophilic fungi disappear. However, a mesophilic fungus, Cladosporium cladosporioides, grew well at $64 \pm 65^{\circ} \mathrm{C}$, but no fungi were detected at $67^{\circ} \mathrm{C}$ (von Klopotek, 1962). In the studies of Thambirajah et al. (1995) and Waksman et al. (1939a,b), no fungi were detected when the temperature was over $60^{\circ} \mathrm{C}$. In the study of Thambirajah and Kuthubutheen (1989) fungi survived at high temperature probably due to the short duration of peak heating. When the temperature decreases below $60^{\circ} \mathrm{C}$ mesophilic and thermophilic fungi reappear in compost (von Klopotek, 1962; Thambirajah et al., 1995). The dominating fungus after peak heating is Aspergillus sp. (Nusbaumer et al., 1996) or Thermomyces lanuginosus (von Klopotek, 1962), which was also found to dominate at $50^{\circ} \mathrm{C}$. $T$. lanuginosus can decompose cellulose, hemi-celluloses and even lignin, although to a much smaller extent than the other components (Waksman et al., 1939a,b). In the studies of Thambirajah and Kuthubu-theen (1989) and Thambirajah et al. (1995) the number of mesophilic and thermophilic fungi $\left(10^{4} \pm 10^{6} / \mathrm{g}\right)$ in mature compost were the same, but in the study of von Klopotek (1962) thermophilic fungi dominated especially in the drier parts of mature compost.

Coprinus sp. (von Klopotek, 1962; Nussbaumer et al., 1996), Panaeolus sp., Corticium coronilla and possibly Mycena sp. (von Klopotek, 1962) are Basidiomycotina occurring in compost. They were all isolated from compost during the cooling and maturation phase or from mature compost (von Klopotek, 1962; Nu-ssbaumer et al., 1996).

\section{Microorganisms during composting}

\section{Compost environment}

During composting microorganisms transform organic matter into $\mathrm{CO}_{2}$, biomass, thermoenergy (heat) and humus-like end-product, (Figs. 1 and 2). The organic substrates, bulking agents and amendments used in composting are mostly derived from plant material. The main components of the organic matter are carbo-hydrates (e.g. cellulose), proteins, lipids and lignin. The capacity of microorganisms to assimilate organic matter depends on their ability to produce the enzymes needed for degradation of the substrate. The more complex the substrate, the more extensive and comprehensive is the enzyme system required. Through the synergistic action of microorganisms complex organic compounds are degraded to smaller molecules which can then be utilized by the microbial cells (Golueke, 1991, 1992).

Microorganisms require a carbon source, macronutrients such as nitrogen, phosphorous and potassium, and certain trace elements for their growth. Carbon serves primarily as an energy source for the microorganisms, while a small fraction of the carbon is incor-porated into their cells. Some of the energy formed is used for microbial metabolism, and the rest is released as heat. Nitrogen is a critical element for microorgan-isms because it is a component of the proteins, nucleic acids, amino acids, enzymes and coenzymes necessary for cell growth and functioning. If nitrogen is a limiting factor during composting the degradation process will be slow. In contrast, if there is excess nitrogen, it is often lost from the system as ammonia gas or other nitrogen compounds. The optimum $\mathrm{C} / \mathrm{N}$ ratio has been reported to be $25 \pm 40$, but the value varies depending on the substrate (Golueke, 1991).

Microorganisms are able to use organic molecules which dissolve in water. If the moisture content falls below a critical level, microbial activity will decrease and the microbes become dormant. On the other hand, too high a moisture content can cause a lack of aeration and the leaching of nutrients. In the subsequent anaerobic conditions the decomposition rate decreases and odour problems arise (Golueke, 1991). 
Under optimal conditions, composting proceeds through three phases: (1) the mesophilic phase, (2) the thermophilic phase, which can last from a few days to several months, and (3) the cooling and maturation phase which lasts for several months. The length of the composting phases depends on the nature of the organic matter being composted and the efficiency of the process, which is determined by the degree of aeration and agitation. At the start of composting the mass is at ambient temperature and usually slightly acidic. Soluble and easily degradable carbon sources, such as mono-saccharides, starch and lipids, are utilized by microorganisms in the early stage of composting. The $\mathrm{pH}$ decreases because organic acids are formed from these compounds during degradation. In the next stage microorganisms start to degrade proteins, resulting in the liberation of ammonium and an increase in the $\mathrm{pH}$. After the easily degradable carbon sources have been consumed, more resistant compounds such as cellulose, hemicellulose and lignin are degraded and partly trans-formed into humus (Crawford, 1983; Paatero et al., 1984).

Humus is the end product of the humification process, in which compounds of natural origin are partially transformed into relatively inert humic substances. Humic substances can be considered as a major reser-voir of organic carbon in soils and aquatic environments (Aiken et al., 1985). The definitive structure of humic substances is not known, but they are usually divided into groups on the basis of chemical fractionation.

Organic matter present in compost is usually chemically complex and di•cult to fractionate. Extraction proce-dures may remove only a fraction of the organic matter, and, consequently, nondestructive methods such as ${ }^{13} \mathrm{C}-\mathrm{NMR}$ (Almendros et al., 1992) and FTIR (Fourier transform IR) (Tseng et al., 1996) spectroscopy have been used for the analysis of humus. Aiken et al. (1985) divided humic substances into the following groups: humin (not soluble in water at any $\mathrm{pH}$ ), humic acids (not soluble in water under acidic conditions) and fulvic acids (soluble in water under all $\mathrm{pH}$ conditions).

In general, immature compost contains high levels of fulvic acids and low levels of humic acids. As the de- composition proceeds, the fulvic acid fraction either decreases or remains unchanged while humic acids are produced. The degree of humification and compost maturity can be evaluated by means of the humification index. The humification index is the ratio between humic acids and fulvic acids $\left(\mathrm{C}_{\mathrm{HA}} / \mathrm{C}_{\mathrm{FA}}\right)$ expressed as a percentage of the total organic carbon (Ri aldi et al., 1986; Inbar et al., 1990; Chen et al., 1996). Chen et al. (1996) studied the formation and properties of humic substances during composting. They found that the humification index increases during the process. The ${ }^{13} \mathrm{C}-\mathrm{NMR}$ spectra of humic acids have been used to study the presence of aliphatic and aromatic structures. Both ${ }^{13} \mathrm{C}-\mathrm{NMR}$ analysis and FTIR spectra indicate that the humic acid fraction extracted from a mature com-post contains more aromatic structures and carboxyl groups and less carbohydrate components than that from an immature compost (Chen et al., 1996).

It has been claimed that humus is mainly formed from lignin, polysaccharides and nitrogenous compounds (Varadachari and Ghosh, 1984; Fustec et al., 1989; Inbar et al., 1989). The chemical pathway from organic matter to humus is very complex and involves a number of degradative and condensation reactions. Several schemes for the formation of humus have been proposed (e.g. Varadachari and Ghosh, 1984; Brown, 1985; Colberg, 1988). According to Varadachari and Ghosh (1984), lignin is first degraded by extracellular enzymes to smaller units, which are then absorbed into microbial cells where they are partly converted to phenols and quinones. The substances are discharged to-gether with oxidizing enzymes into the environment, where they polymerized by a free-radical mechanism.

Composting is a dynamic process carried out by a rapid succession of mixed microbial populations. The main groups of microorganism involved are bacteria, including actinomycetes, and fungi (Golueke, 1991). Although the total number of microorganisms does not significantly change during composting, the microbial diversity can vary during the different phases of com-posting (Atkinson et al., 1996a). The precise nature of succession and the number of microorganims at each composting phase is dependent on the substrate and on the preceding microorganisms in the succession (Craw-ford, 1983). 
At the beginning of composting mesophilic bacteria predominate, but after the temperature increases to over $40^{\circ} \mathrm{C}$, thermophilic bacteria take over and thermophilic fungi also appear in the compost. When the temperature exceeds $60^{\circ} \mathrm{C}$, microbial activity decreases dramatically, but after the compost has cooled mesophilic bacteria and actinomycetes again dominate (McKinley and Vestal, 1985; Strom, 1985a).

Composting is an aerobic process in general, but anaerobic microenvironments may develop. Atkinson et al. (1996b) estimated that almost $1 \%$ of all the bacteria found in municipal solid waste compost were anaerobic. All the anaerobic bacteria found were highly cellulolytic and thus may play a significant role in the degradation of macromolecules. The majority of the mesophilic anaerobic bacteria were facultative, while under thermophilic conditions more obligate anaerobic bacteria were found (Atkinson et al., 1996b).

\section{Fungal Incubation}

Sacrau poplar was harvested from the experimental farm at Beijing Forestry University, Beijing, China. Before treatment, the wood sample was ground to pass through a 0.9 -mm-sized screen. Two fungal strains, T. pubescens C7571 and T. versicolor C6915, were collected from Guangdong and Hebei provinces in China, respectively. Biological treatment was carried out in a 250-mL Erlenmeyer flask with $5 \mathrm{~g}$ of air-dried poplar wood and $12.5 \mathrm{~mL}$ of distilled water. The samples were sterilized in the autoclave for 20 min at $121^{\circ} \mathrm{C}$ and inoculated with $5 \mathrm{~mL}$ of inoculum. The cultures were incubated statically at $28^{\circ} \mathrm{C}$ for 4 , 8,12 , and 16 weeks. The non-inoculated sample served as the control. All experiments were performed in triplicate.

\section{Lignin Reduction by Fungi}

Aerobic and anaerobic organisms produce carbon dioxide and glucose release, relatively. The most important group of microorganisms in cellulose reduction are Basidiomycetes (white- and brown-rot fungi), Ascomycetes, Deuteromycetes (soft-rot fungi), and anaerobic (rumen) fungi. Lignin biodegradation because of its complex structure and macromolecular features is complicated. A few microorganisms are identified to reduce lignin partly, which decrease just the polysaccharide component. Nevertheless, lignin virtually includes sugars, it is probably that these procedures rely on energy obtained from the sugars. It takes maximum time to achieve roughly $10 \%$ lignin degradation under 1,000 Daltons in molecular weight. For the hydrolysis of lignin oxygen is an essential principle.

Many different environmental factors influence lignin degradation. The environmental parameters motivate lignin degradation by increasing growth and metabolism of the fungi. Temperature, acidity, carbon and nitrogen sources are the major prominent parameters that affect fungal growth. In the fungal growth, combined nitrogen at the low and high contents perform an efficient function. Lignin degradation is optimum at low nitrogen level. The hydrolyzation of cellulose by fungi is more harder than hemicelluloses hydrolyzation. White-rot fungi are one of the extremely skilled fungi in lignin reduction in nature.

\section{White-rot fungi}

White-rot fungi is the only organism that can decrease lignin faster than other organisms. Moreover, in nature the responsibility of white-rot fungi in lignin saccharification is high. Basidiomycetes are the important identified white-rot fungi. Under aerobic environment $P$. chrysosporium can reduce one gram of different separated lignins in two days. It influence in creation of about $70 \% \mathrm{CO}_{2}$ and $30 \%$ low-molecular-weight water-soluble compounds. The fungus uses lignin, hemicelluloses, and cellulose as substrate. The lignin reduction happens at the end of primary growth by cooperation of other metabolism like nitrogen. The oxidation reactions are involved in the fungal attack which decreases methoxy, phenolic, and aliphatic content of lignin. These reactions also cleave aromatic rings, and forms new carbonyl groups. Selective type of degradations involves degradation of lignin and hemicellulose compared to cellulose. For example, C. subvermispora, Dichomitus squalens, $P$. chrysosporium follow selective decay mechanism. Similarly, simultaneous, or non-selective type of degradation is the type of digestion in which all the components of lignocellulose are decayed irrespectively (e.g. Trametes versicolour and Fomes 
fomentarius). White-rot fungi are identified to grow on woody and herbaceous plants. The most examined white-rot fungi for lignin reduction in a selective way are P. chrysosporium and Phlebia while in a nonselective way Trametes versicolor decrease lignin.

At the high concentration, white-rot fungi can decrease pollution. In addition, since the lignin reduction system is non-particular and free white-rot fungi have an ability to decrease various contaminations. For the cultivation of fungi costeffective substrates and various liquid medias are being used. Fungi have special oxygenic radicle which has ability to oxidize to biomolecules of other organisms that cause the death of the particular microorganism. By altering medium $\mathrm{pH}$ other microbe cannot easily growth into the medium, because of preventing of fungus. Moreover, many different genes create by fungi which can convert lignin into water-soluble compounds.

\section{Soft-rot fungi}

Most of the soft-rot fungi have identified from Deuteromycotina or Ascomycotina. These fungi are very skilled to decrease lignin in woody plants more than herbaceous crops. Soft rot fungi are degrading wood components very slowly as compared to whiterot and brown-rot fungi. The best place for the growth of soft-rot fungi are compost, soil, piles of woodchips, straw. Soft-rot fungi can reduce cellulose and hemicellulose of woody plants in a slowly way, whereas lignin reduction is somewhat slight. The adaptation of soft-rot fungi in various temperature, different $\mathrm{pH}$ and limited oxygen is higher than other fungi.

Soft rot fungi are no doubt the most efficient fungi to degrade lignin in mixed microbial populations.

\section{Brown-rot fungi}

Brown-rot fungi degrades cellulose and hemicellulose more faster than lignin. Moreover, Compare with other fungus and bacteria the way of digestibility of plant cell wall by brown-rot fungi is entirely different, because the reduction mechanism is non-enzymatic and lacks of exoglucanases. Phenolic and non-phenolic de-methylation result in chemical alteration in lignin which outcome of aromatic hydroxylation and ring splitting. In the wood presence lignin de-methylation is operated by brown-rot . Brown-rot fungi more effectively grown on herbaceous crops than woody plants. Among the brown-rot fungi generally Serpula lacrymans and Gloephyllum trabeum can destruct the structure of woody plants without difficulty. The residues of brown-rot fungi is brown in colour which composed of changed lignin and also remains in the nature lacking any more hydrolysis .

\section{Molds}

Most of deuteromycetes and certain ascomycetes which are actually called Microfungi or molds, i.e. are usually thought to degrade mainly carbohydrates in soil, forest litter, and compost, can also degrade lignin in these environments. These molds are able to mineralize grass lignin up to $27 \%$. Among the molds the Penicillium chrysogenum, Fusarium oxysporum, and Fusarium solani have been identified for their lignnolytic activities in forests. These molds or microfungi mineralized $27.4 \%, 23.5 \%$, and $22.6 \%$ of a 14 C-labeled lignin prepared from milled wheat straw. However, lignin prepared from pine was much less degraded, and mineralization rate of less than $3 \%$ was obtained. The degradation of lignin has been also being studied in the red mold of bread (Chrysonilia sitophila). These fungi caused 20\% weight loss of pine wood in 3 months, with the losses of carbohydrate and lignin being $18 \%$ and $25 \%$, respectively. Analysis of the decayed lignin suggested that oxidative $\mathrm{Ca} \pm \mathrm{Cb}$ and b-O-aryl cleavages occurred during lignin degradation. Recently another mold Neurospora discrete was found to degrade lignin in sugarcane bagasse and produced nearly 1.5 times the amount of lignin degradation products in submerged culture. Based on this data, $N$. discrete is recorded to have high lignin degrading capability than previously reported lignin degrading fungi.

\section{Lignin-degrading enzymes from fungi}

The structure of lignin mainly composed of phenolic and non-phenolic components. Lignin forms an integral part of secondary walls in plants and it plays an important role in enhancing the efficiency of water conduction in vascular plants. In the lignin, digestibly many various fungi and bacteria are 
proficient for genes production. These enzymes comprising of lignin peroxidases (e.g. lignin peroxidase (E.C. 1.11.1.7), and manganese peroxidase (E.C. 1.11.1.7)) and laccases as well. These are hemecontaining glycoprotein which requires hydrogen peroxide as oxidant. Lignin peroxidase degrades non-phenolic lignin units. Manganese peroxidase acts on phenolic and nonphenolic lignin units through lipid peroxidation reactions. It oxidizes $\mathrm{Mn} 2+$ to $\mathrm{Mn} 3+$ which oxidizes phenol rings to phenoxy radicals leading to decomposition of compounds.

P. chrysosporium, Ceriporiala cerata, Cyathus stercolerus, C. subvermispora, Pycnoporus cinnarbarinus, and Pleurotus ostreaus produce enzymes which are involve in lignin degradation.

Laccases (E.C. 1.10.3.2.) are copper containing enzymes which are involved in lignin degradation. Laccases acts along with lignin peroxidase and manganese peroxidase leading to complete degradation of lignin. It catalyzes the oxidation of phenolic units in lignin and phenolic compounds and aromatic amines to radicals. The capability of laccase in lignocelluloses degradation is improved by phenolic components such as 3-hydroxyanthranilic acid, 3-ethylthiazoline-6-sulfonate which will act as redox mediators. Without the role of redox mediators laccases have a limited effect.

Other enzymes like aryl alcohol dehydrogenase, cellobiose, aromatic acid reductase, vanillate hydroxylase, dioxygenase and catalase are regarded to contribute an important function in lignin reduction. The number of research investigations on the soft-rot fungi enzyme system and their degradation of lignin is low. Peroxidases and laccase provide by $F$. oxysporum, Xylaria sp., and Altenaria sp., Botrytis cinerea, Myceliophthora thermophila, Chaetomium thermophilium and Paecilomyces farinosus. Although, laccase provide by soft-rot fungi in a low proportion compared to white-rot fungi.

\section{Fungal extracellular ligninases}

Fungi degrade lignin by secreting enzymes collectively termed "ligninases". Ligninases can be classified as either phenol oxidases (laccase) or heme peroxidases [lignin peroxidase (LiP), man- ganese peroxidase $(\mathrm{MnP})$ and versatile peroxidase (VP). In general, laccases use molecular oxygen as electron acceptors while peroxidases use hydrogen peroxide as a co-substrate. White-rot fungi variously se- crete one or more of the lignin-modifying en- zymes (LMEs) in addition to other compounds necessary for effective lignin degradation. It has been shown that $P$. chrysosporium produces several LiP and MnP isoenzymes but no laccase. Correspondingly, the genome of $P$. chrysospo- rium contains ten LiP and five $\mathrm{MnP}$ genes. In addition, $\mathrm{H} 2 \mathrm{O} 2$-generating enzyme, glyoxal oxidase (GLOX) has been found in $P$. chrysospo- rium cultures . White-rot basidiomycetes, such as Coriolus versicolor, $P$. chrysospo-rium and T. versicolor, have been found to be the most efficient lignin-degrading microorganisms studied. Although LiP is able to oxidize the non-phenolic part of lignin (which forms $80-90 \%$ of lignin composition), it is absent from many lignin degrading fungi. In addition, electron microscopy studies of the early stages of the fungal degradation of wood have shown that oxidative ligninolytic enzymes are too large to penetrate into the wood cell wall micropores. Thus, it has been suggested that prior to the enzymatic attack, low-molecular weight dif- fusible reactive oxidative compounds must initiate changes to the lignin structure (as dis- cussed below). n summarized the major steps and enzymes involved in lignin degradation by basidiomycetes white-rot fungi.

Phenol oxidases (laccases) (benzenediol:oxygen oxidoreductases,)

\section{Lignin Peroxidase (LiP)}

Lignin peroxidase (LiP, EC 1.11.1.14) is a glycosylated enzyme containing heme protein with an iron protoporphyrin prosthetic group that requires hydrogen peroxide ( $\mathrm{H} 2 \mathrm{O} 2)$ to catalyze the oxidation of non-phenolic lignin units and mineralize the recalcitrant aromatic compounds. Lignin oxidation takes place via electron transfer, non-catalytic cleavages of various bonds, and aromatic ring opening. The catalytic cycle of LiP consists of one oxidation and two reduction steps as follows:

Step 1 Two-electron oxidation of the resting (native) ferric enzyme ([LiP]-Fe(III)) by $\mathrm{H} 2 \mathrm{O} 2$ to form the Compound I oxo-ferryl intermediate [Fe(IV)]; 
Step 2 Reduction of Compound I by the nonphenolic aromatic reducing substrate (A) to form Compound II by gaining one electron;

Step 3 Finally, the oxidation cycle ends when Compound II is returned to the resting ferric state with a gain of one more electron from the reducing substrate A.

LiPs have a high redox potential (1.2 $\mathrm{V}$ at $\mathrm{pH}$ 3.0) as compared with other peroxidases and can oxidize phenolic and nonphenolic structures of lignin directly without a mediator.

\section{Manganese Peroxidase (MnP)}

Manganese $(\mathrm{Mn})$ is essential for the formation of $\mathrm{MnP}$. The enzyme MnP plays an important role during the initial stages of lignin degradation. Compared to laccase, $\mathrm{MnP}$ causes greater degradation of phenolic lignin due to its higher redox potential with the eventual release of carbon dioxide. $\mathrm{MnP}$ is mainly produced by a broad species of whiterot basidiomycetes such as Phanerochaete chrysosporium .

The catalytic cycle of $\mathrm{MnP}$ is similar to that of LiP. Like LiPs, MnPs are also hemecontaining glycoproteins which require $\mathrm{H} 2 \mathrm{O} 2$ as an oxidant. Manganese acts as a mediator during MnP enzymatic activity. To begin with, MnP oxidizes $\mathrm{Mn} 2+$ to $\mathrm{Mn} 3+$. The enzymatically generated Mn3+ oxidant is freely diffusible and participates in the oxidation reaction as a redox couple.

In addition, organic acids such as lactate and malonate can chelate $\mathrm{Mn} 3+$ ion. The chelated Mn3+- organic acid complex oxidizes the phenolic compounds in lignin to phenoxy radicals. High levels of $\mathrm{Mn}$ can stimulate MnP enzymatic activity and enhance the degradation process of lignin in soils.

\section{Versatile Peroxidase (VP)}

Versatile peroxidase, as the name suggests, has catalytic properties of both $\mathrm{LiP}$ and MnP. VP was first purified from the genera of fungi Bjerkandera and was found to transform lignin even without an external mediator.

The VP enzyme possesses a hybrid molecular architecture with several binding sites including $\mathrm{Mn} 2+$ and is able to oxidize Mn2+ like MnP and LiP.
However, unlike MnP, VP has the dual ability to oxidize $\mathrm{Mn} 2+$ in the independent oxidation of simple amines and phenolic monomers. VP can also oxidize a variety of substrates (with high and low redox potentials) including $\mathrm{Mn} 2+$, phenolic and nonphenolic lignin dimers, and aromatic alcohols.

\section{Laccase (Lac)}

Lac (EC 1.10.3.2, p-diphenol oxidase) is a coppercontaining enzyme belonging to the oxidoreductase group which oxidizes a wide variety of organic and inorganic substances. Lac was extracted by Yoshida in 1883 for the first time from the Rhus vernicifera tree. In 1896, it was first showed to be present in fungi by Bertrand and Laborde. Thereafter, many Lacs have been identified from fungi. The white-rot fungus produces high levels of Lac and is very efficient at decolorizing dyes.

It was initially assumed that Lac could only oxidize phenolic compound, due to its lower redox potential $(450-800 \mathrm{mV})$ as compare to Lips $(>1 \mathrm{~V})$. However, with the involvement of a mediator, a wide variety of substance can be oxidized using Lac.

Mediators are low molecular weight compounds that are easily oxidized by Lacs and subsequently reduced by the substrate. Due to its large size, the substrate cannot reach the active site of the enzyme. A mediator, due to its small size, acts as a conveyer of an electron from the enzyme to the substrate. The mediator reaches the enzyme active site easily and gets oxidized to a more stable intermediate with a high redox potential. The oxidized mediator diffuses away from the enzyme and oxidizes more complex substrates before returning to its original state. The electrons taken by Lacs are finally transferred back to oxygen to form hydrogen peroxide.

Most of the enzymes are substrate specific, in contrast to Lac activity which oxidizes a variety of substrates like polyphenols, diphenols, benzenethiol, and aromatic amines.

\section{Dye-Decolorizing Peroxidase (DyP)}

The DyP enzyme is also a heme-based peroxidase that can cause lignin breakdown through a radicalmediated oxidation process. The DyPs are phylogenetically distinct from other peroxidases as they possess an $\alpha+\beta$ ferredoxin-like fold. However, 
their oxidation mechanism is similar to VP and MnP. They are widely found in microorganisms and classified into four types: A, B, C, and D. Bacterial enzymes are predominantly found in type $\mathrm{A}$ to $\mathrm{C}$, while type D is mostly clustered to fungal DyPs. All kinds of DyPs have peroxidase activities; however, they differ in substrate specificity values. In addition to lignin, DyPs can also oxidize synthetic dyes, nonphenolic methoxylated aromatics, Mn2, and high redox synthetic dyes such as anthraquinone and azo dyes.

\section{Enzyme Assays}

The enzymes were extracted with $50 \mathrm{mM}$ sodium acetate buffer ( $\mathrm{pH}$ 5.5) supplemented with Tween 60 $(0.1 \mathrm{~g} / \mathrm{L})$. The entire contents of each bioreactor was transferred to an Erlenmeyer flask and extracted with $500 \mathrm{~mL}$ of extracting solution. Five successive extractions were performed at $120 \mathrm{rpm}$ for $4 \mathrm{~h}$ at 10 $\pm 1{ }^{\circ} \mathrm{C}$. After the second extraction, the wood chips were stored overnight while soaking in the extraction solution at $4{ }^{\circ} \mathrm{C}$. The crude extracts were recovered by filtration through a fine filter paper (Souza-Cruz et al. 2004). Enzyme activities were determined at 25 ${ }^{\circ} \mathrm{C}$ using a Helios gamma UV-OnVis spectrophotometer (Thermo Fischer Scientific, California, USA). Manganese peroxidase activity was determined according to the modified method of Heinfling et al. (1998) by the formation of $\mathrm{Mn}^{3+-}$ tartrate $(\varepsilon 238=6500 \mathrm{M} / \mathrm{cm})$ from $0.10 \mathrm{mM} \mathrm{MnSO} 4$ using $100 \mathrm{mM}$ tartrate buffer $(\mathrm{pH} \mathrm{5)}$ and $0.10 \mathrm{mM}$ $\mathrm{H}_{2} \mathrm{O}_{2}$. Lignin peroxidase activity was monitored at pH 3.0 according to Tien and Kirk (1988), and the formation of veratraldehyde was monitored at 310 $\mathrm{nm} \quad(\varepsilon 310=9.3 \mathrm{mM}-1 \mathrm{~cm}-1)$. Laccase was measured following the oxidation of $2.0 \mathrm{mM} \mathrm{2,2}$ azino-bis (3-ethylbenzthiazoline-6-sulphonic acid, ABTS) at $420 \mathrm{~nm}$ (Dias et al. 2004). Hemicellulase activity was measured according to Ghose and Bisaria (1987). The liberated reducing sugars were quantified using dinitrosalicylic acid (DNS) reagent (Miller 1959).

\section{Fenton Chemistry in Lignin Degradation}

Brown-rot fungi hydrolyze and partially oxidize the lignocellulose component of the plant cell wall, in contrast to white-rot fungi which produce an array of extracellular lignin-degrading enzymes. During the oxidation process, a hydroxyl ion is generated via Fenton oxidation chemistry. The Haber-Weiss reaction is a specific example of the Fenton reaction. In Haber-Weiss reaction, ferrous salt and hydrogen peroxide react to produce a highly reactive hydroxyl

\section{Poplar}

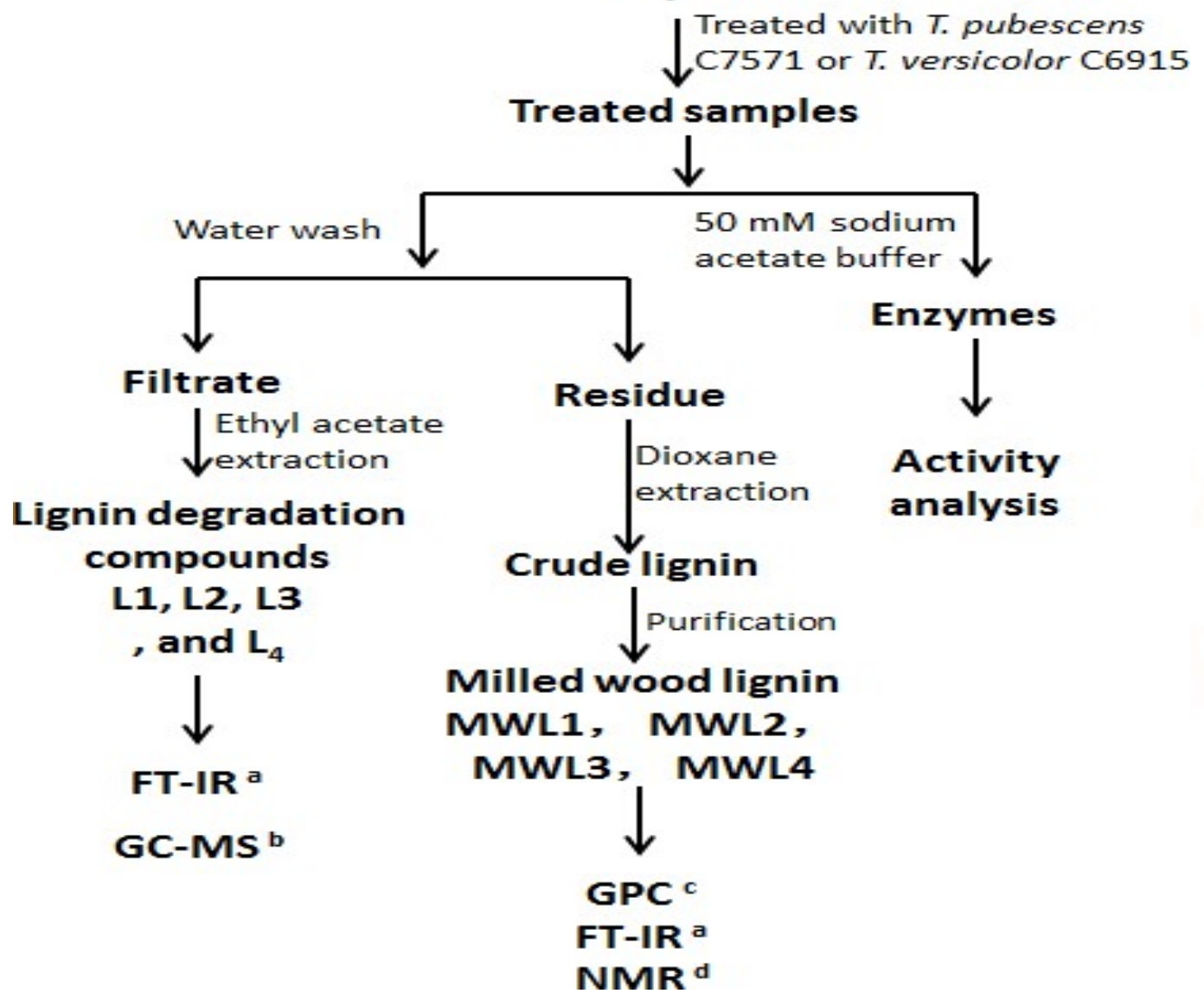


free radical capable of oxidizing a wide verity of substrates. In a nutshell, Fenton reaction is a cyclic redox reaction. In the Fenton reaction, there is neither a breaking of old bonds nor the formation of new bonds. As a result, a highly reactive hydroxyl radical is produced.

A detailed mechanism of the Fenton reaction has been explained using two extracellularly produced quinones, 2,5-dimethoxy-1,4-benzoquinone (2,5DMBQ) and 4,5-dimethoxy-1,2-benzoquinone (4,5DMBQ), in Gloeophyllum trabeum. The two hydroquinones have the ability to reduce ferric oxalate salt to ferrous oxalate. In the second step, ferrous oxalate reacts with hydrogen peroxide to generate highly reactive hydroxyl free radicals. This reactive hydroxyl free radical can react with many organic compounds including lignin. Quinone is then converted back to hydroquinone by fungi.

\section{Low Molecular Weight Compounds Involved in Lignin Degradation}

Electron microscopy studies haven shown that enzymes such as peroxidase and laccase, due to their larger size than that of the pores of the cell wall, cannot reach to the native lignin molecule. Therefore, mediators are important parts of the ligninolytic enzyme system. Mediators help enzymes such as $\mathrm{MnP}$ and $\mathrm{LiP}$ to reach native lignin present in the wood.

Many low molecular weight compounds have been identified which could play a fundamental role in the enzymatic ligninolytic systems of white-rot fungi. Lip and MnP can oxidise various lignin compounds and synthetic lignin only in the presence of a cofactor.

Lignin degradation conditions support both depolymerization and repolymerization, so it is important to optimize several factors, such as $\mathrm{H}_{2} \mathrm{O}_{2}$ and lignin concentration, $\mathrm{O}^{2}$, and the presence of a suitable mediator.

\section{Manganese}

A high amount of manganese (10-100 mg/kg of dry wood) is present in the wood. Manganese deposits were found in wood decay resulting from white-rot fungi activity. Scanning electron microscopy revealed a 100 -fold increase in manganese concentration as compared to delignified wood. $\mathrm{Mn}^{2+}$ precipitates in the form of $\mathrm{MnO}^{2}$.

During lignin degradation, $\mathrm{Mn}^{3+}$ assists oxidation of various phenolic compounds whereas $\mathrm{Mn}^{2+}$ acts as a substrate and triggers $\mathrm{MnP}$ production. $\mathrm{Mn}^{2+}$ is a scavenger of the peroxide radical and it decreases the oxygen stress of cell, resulting in decreased LiP production, whereas it increases under an oxidizing atmosphere. Furthermore, $\mathrm{Mn}^{2+}$ induces MnsoD which further minimizes oxidative stress as well.

\section{Veratryl Alcohol}

Veratryl alcohol (VA) is synthesized from glucose. Its production starts in parallel with LiP production during the early phase of secondary metabolism. Mester et al. showed that manganese inhibits the production of VA in fungi Bjerkandera sp. strain BOS55 and P. chrysosporium.

In addition to de novo synthesis from glucose, several alternative pathways are present for VA production in Phlebia radiata. De novo synthesis of VA is repressed when products of lignin degradation are used as precursors.

A is most likely the physiological substrate of LiP. Production of Lip and VA is triggered by the presence of secondary lignin metabolites. The introduction of VA to culture medium has been found to increase LiP. VA plays a key role in LiPcatalyzed oxidation reactions and LiP-mediated electron transfer reactions.

\section{Oxalate}

White-rot fungi secrete oxalate as a major aliphatic organic acid. White-rot fungi decompose oxalate to carbon dioxide and formate as they cannot accumulate acid. This is further oxidized to a superoxidized form under aerobic conditions. This superoxide directly participates in the oxidation of lignin.

The enzymes oxaloacetate and glyoxylate oxidase are responsible for the biosynthesis of oxalate.

$\mathrm{LiP}$ and $\mathrm{MnP}$ can decompose oxalate in the presence of VA or $\mathrm{Mn}^{2+}$. 
Oxidation of oxalate is necessary; it can slow down the lignin mineralization by reducing $\mathrm{VA}^{+*}$ and $\mathrm{Mn}^{2+}$.

\section{2-Chloro-1,4-dimethoxybenzene}

Chlorinated anisyl metabolites (CAMs) are physiologically involved in lignin degradation. CAMs act as a substrate for the aryl alcohol oxidase enzyme involved in extracellular peroxide production. White-rot fungi produce a wide variety of halogen metabolites. CAMs and chlorinated hydroquinone metabolites (CHMs) are the most common.

The CHM biosynthesis pathway involves the formation of 9 metabolites found in basidiomycetes. Among these, 9,2-chloro-1,4-dimethoxybenzene, 2,6-dichloro-1,4-dimethoxybenzene, tetrachloro-1,4dimethoxybenzene, and tetrachloro-4-methoxy phenol were identified.

\section{2-Chloro-1,4-dimethoxybenzene}

(2-Cl-1,4-DMB) acts as a substrate for LiP and is actively involved in lignin degradation and acts as a redox mediator. DMB free radicals are formed during LiP-catalyzed oxidation. These free radicals easily diffuse away from enzyme active site and are regarded as diffusible redox mediators.

2-Cl-1,4-DMB involvement in lignin degradation is still not clear as the formation of LiP and its biosynthesis do not coincide.

\section{Lignin Component Changes}

The decrease in lignin content differed between the two fungi-treated samples during different periods (Fig. 3). A lignin decrease of $6.6 \%$ (from $23.5 \%$ to $16.9 \%$ ) and $5.1 \%$ (from $23.5 \%$ to $18.4 \%$ ) was measured in the initial degradation period of $T$. pubescens C7571 and T. versicolor C6915, respectively. During this treatment period (week 4), LiP was the only enzyme whose activity was higher in T. pubescens C7571 than in T. versicolor C6915 (Fig. 2). This result was explained by the fact that LiP oxidizes non- phenolic lignin (Umezawa et al. 1987). Between week 4 and week 8 , the decrease was approximately $2.7 \%$ for both types of white-rot fungi. Thus, there was a first phase ( 0 to 4 weeks) of growth, during which a rapid decrease in lignin was observed, and a second phase in which the values remained fairly stable. Additionally, during this treatment period, nearly all enzyme activity for $T$. pubescens C7571 was higher than that of $T$. versicolor C6915, except for that of hemicellulase. Hemicellulases are extremely important in the degradation of lignocellulosic biomass because of their lignin-carbohydrate complexes (LCCs) (Dinis et al. 2009). During week 16, T. pubescens C7571 showed higher activity for all three enzymes during the last treatment period (Fig. 2), thus yielding a low lignin content of $10.4 \%$. A recent study also demonstrated the low enzyme producing capabilities of $T$. versicolor that laccase and $\mathrm{MnP}$ activity was only detectable and no LiP activity was detected (Kuhar et al. 2015). The results of enzyme activities as well as lignin component changes confirmed that the ability of $T$. versicolor to remove lignin was weaker than $T$. pubescens C7571. Chemical analyses in other studies have also indicated that this species is a non-selective type and that it removes all types of cell-wall constituents not only lignin (Bari et al. 2015). In summary, lignin degradation varied during different treatment periods; because T. pubescens C7571 showed a higher capacity for lignin degradation, it was considered for more specific studies.

\section{Chemical Component Analysis and Molecular Weight of Extracted Lignin}

To reveal the effect of white-rot fungi treatment on the structural changes of lignin, MWL1, MWL2, MWL3, and MWL4 from T. pubescens C7571treated poplar were further investigated. The sugar analysis of the extracted lignin fractions is listed in Table 1. The lignin fraction from the untreated sample had a relatively higher amount of sugar $(6.49 \%)$ than the treated samples. Comparatively, MWL4 obtained from treated samples during the last 16 weeks had the lowest amount of bound sugars $(0.97 \%)$. This result might be caused by the destruction of linkages between lignin and carbohydrates by the hemicellulase in white-rot fungi (Dinis et al. 2009). In all cases, xylose was the predominant sugar $(0.28$ to $3.06 \%)$, followed by mannose, glucose, and galactose, with a small amount of arabinose. An increase in treatment time 
from 4 to 16 weeks resulted in a noticeable decrease in xylose content (from $0.92 \%$ to $0.28 \%$ ).

The molecular weight distribution of the extracted lignin samples was analyzed using gel permeation chromatography (GPC). Changes in the molecular weights of lignin provide insights to lignin fragmentation and re-condensation reactions during bio- treatment. As shown in Table 2, all lignin fractions possessed narrow molecular weight distributions $(M \mathrm{w} / M \mathrm{n}$, lower than 1.5). The molecular weight of the MWL0 sample was $M \mathrm{w}$ $3585.6 \mathrm{~g} / \mathrm{mol}$ and $M \mathrm{n} 2451.5 \mathrm{~g} / \mathrm{mol}$. When treated for 4 to 12 weeks, the extracted lignin had low molecular weights $(2555.3$ to $3226.4 \mathrm{~g} / \mathrm{mol}$ and 1773.0 to $2250.0 \mathrm{~g} / \mathrm{mol}$ ). A significant reduction in molecular weight was observed in the lignin fraction MWL4 (Mw $2555.3 \mathrm{~g} / \mathrm{mol}$ and $M \mathrm{n} 1773.0 \mathrm{~g} / \mathrm{mol}$ ). The decrease in molecular weight indicated that lignin was fragmented during bio-treatment.

\section{FT-IR Spectra of the Extracted Lignin}

To better understand lignin structural changes, the extracted lignin fractions were characterized by FTIR spectroscopy (Fig. 4). The spectra of samples from weeks $4,8,12$, and 16 were rather similar. The band at $1024 \mathrm{~cm}-1$ was indicative of the aromatic C$\mathrm{H}$ in- plane deformation. The strong band at 1219 $\mathrm{cm}^{-1}$ was caused by $\mathrm{C}-\mathrm{C}, \mathrm{C}-\mathrm{O}$, and $\mathrm{C}=\mathrm{O}$ stretching. Syringyl (S) and condensed guaiacyl (G) absorptions were clearly observed at $1329 \mathrm{~cm}^{-1}$, whereas guaiacyl ring breathing with $\mathrm{C}=\mathrm{O}$ stretching appeared at $1373 \mathrm{~cm}^{-1}$. The bands at 1420, 1503, and $1591 \mathrm{~cm}^{-1}$ corresponding to the aromatic skeletal vibrations, and the $\mathrm{C}-\mathrm{H}$ deformation combined with the aromatic ring vibration at 1462 $\mathrm{cm}-1$ were present in these five spectra. The absorption at $1662 \mathrm{~cm}^{-1}$ was attributed to the carbonyl stretching in conjugated p-substituted aryl ketones. A wide absorption band at $3452 \mathrm{~cm}^{-1}$ originated from the $\mathrm{OH}$ stretching vibration in aromatic and aliphatic $\mathrm{OH}$ groups, whereas the bands at 2840, 2887, and $2937 \mathrm{~cm}^{-1}$ arose from the C-H asymmetric and symmetrical vibrations in the methyl and methylene groups, respectively. The lignin degraded by white- rot fungi revealed an intensity at the $1662 \mathrm{~cm}^{-1}$ band assigned to $\mathrm{C}=\mathrm{O}$ in conjugated carbonyl groups, and untreated lignin showed this absorbance to a lesser extent. Moreover, a strong increasing intensity at the 1688 to $1708 \mathrm{~cm}-1$ band was recorded in degraded lignin, which indicated unconjugated carbonyl groups. The results showed that during the bio- treatment of lignin, white-rot fungi generated conjugated and unconjugated $\mathrm{C}=\mathrm{O}$, which suggests that lignin biodegradation involved oxidation.

\section{D HSQC NMR Analysis of the Extracted Lignin}

Two-dimensional 1H-13C NMR (2D NMR) provided important structural information and allowed for the resolution of otherwise overlapping resonances observed in either the $1 \mathrm{H}$ or $13 \mathrm{C}$ NMR spectra. To understand the detailed structural changes in the lignin fractions, they were characterized by 2D HSQC NMR. The HSQC NMR spectra of lignin showed two regions corresponding to the side chain (Fig. 5(a) and (b)) and aromatic 13C-1H correlations (Fig. 5(c) and (d)). The HSQC spectra of untreated wood lignin and treated lignin were similar, which meant that the main structure of lignin remained the same. In the side-chain regions of the HSQC spectra of these two lignin fractions, cross-signals of methoxyls $(\delta \mathrm{C} / \delta \mathrm{H} 56.0 / 3.75)$ and side chains in $\beta-\mathrm{O}$ $4^{\prime}$ aryl ether linkages were the most prominent. The $\mathrm{C} \gamma-\mathrm{H} \gamma$ correlations in $\beta-\mathrm{O}-4^{\prime}$ substructures were observed at $\delta \mathrm{C} / \delta \mathrm{H} 72.1 / 4.85$ (structures $\mathrm{A}, \mathrm{A}^{\prime}$, and $A^{\prime \prime}$ (Fig. 6). The $\mathrm{C} \beta-\mathrm{H} \beta$ correlations corresponding to the erythro and threo forms of the S-type $\beta-\mathrm{O}-4^{\prime}$ substructures were distinguished at $\delta \mathrm{C} / \delta \mathrm{H} \mathrm{86.0/4.10}$ and 86.0/3.98, respectively. These correlations shifted to $\delta \mathrm{C} / \delta \mathrm{H} 83.9 / 4.29$ in structure A linked to the $\mathrm{G} / \mathrm{H}$ lignin units and $\gamma$-acylated $\beta-\mathrm{O}-4^{\prime}$ aryl ether substructures $\left(\mathrm{A}^{\prime}\right.$ and $\left.\mathrm{A}^{\prime \prime}\right)$ linked to the $\mathrm{S}$ lignin unit. The $\mathrm{C} \gamma-\mathrm{H} \gamma$ correlations in structure A were observed at $\delta \mathrm{C} / \delta \mathrm{H} 59.5$ to $59.7 / 3.41$ to 3.64 . In addition to the $\beta-\mathrm{O}-4^{\prime}$ ether substructures, $\beta-\beta^{\prime}$ (resinol, B) and $\beta-5^{\prime}$ (phenylcoumaran, $C$ ) linkages were observed. Strong signals for resinol substructures $\mathrm{B}$ were observed with $\mathrm{C} \gamma-\mathrm{H} \gamma, \mathrm{C} \beta-\mathrm{H} \beta$, and the double $\mathrm{C} \gamma-\mathrm{H} \gamma$ correlations at $\delta \mathrm{C} / \delta \mathrm{H} 85.0 / 4.70,53.8 / 3.09$, and 71.1/4.19/3.84, respectively. Phenyl coumarin substructures $\mathrm{C}$ were found in lower amounts. The signals for their $\mathrm{C} \gamma-\mathrm{H} \gamma$ and $\mathrm{C} \beta-\mathrm{H} \beta$ correlations were discovered at $\delta \mathrm{C} / \delta \mathrm{H} \quad 87.0 / 5.49$ and 53.1/3.47, respectively, whereas the $\mathrm{C} \gamma-\mathrm{H} \gamma$ correlations overlapped with other signals at approximately $\delta \mathrm{C} / \delta \mathrm{H} 62.5 / 3.73$. In addition, $\mathrm{C} \gamma-\mathrm{H} \gamma$ correlations (at $\delta \mathrm{C} / \delta \mathrm{H} 61.4 / 4.10)$ in the $p$-hydroxycinnamyl alcohol end group (I) and various signals from the associated 
carbohydrates and polysaccharide from fungi $(\delta \mathrm{C} / \delta \mathrm{H}$ 65.0 to $77.1 / 2.9$ to 4.2 ) were found in the side-chain regions of the lignin HSQC spectra.

In the aromatic regions of the HSQC spectra, crosssignals from the S- and G-lignin units were observed. The S-lignin units showed a prominent signal for the $\mathrm{C}_{2,6}-\mathrm{H}_{2,6}$ correlation at $\delta \mathrm{C} / \delta \mathrm{H} 104.0 / 6.70$, whereas the $\mathrm{G}$ units showed different correlations for $\mathrm{C} 2-\mathrm{H}_{2}$, $\mathrm{C}_{5}-\mathrm{H}_{5}$, and $\mathrm{C}_{6}-\mathrm{H}_{6}$ at $\delta \mathrm{C} / \delta \mathrm{H} 111.1 / 6.99,115.1 / 6.78$, and 119.1/6.81, respectively. Signals corresponding to the $\mathrm{C}_{2,6}-\mathrm{H}_{2,6}$ correlations in Ca-oxidized $\mathrm{S}$ units (S') $(\delta \mathrm{C} / \delta \mathrm{H} 105.3 / 7.31)$ were present in all of the HSQC spectra of these two lignin fractions. The correlation for the $\mathrm{C}_{2}-\mathrm{H}_{2}$ in oxidized a-ketone structures $\mathrm{G}^{\prime}$ was observed in the spectra of $\mathrm{MWL}_{0}$, and became stronger in the spectra of $\mathrm{MWL}_{4}$. The $\mathrm{C}_{2,6}-\mathrm{H}_{2,6}$ correlations of $\mathrm{PB}$ were observed as a strong signal at $\delta \mathrm{C} / \delta \mathrm{H} 131.3 / 7.69$. The signal at $\delta \mathrm{C} / \delta \mathrm{H} \mathrm{123.0/7.6} \mathrm{might} \mathrm{be} \mathrm{assigned} \mathrm{to} \mathrm{vanillic} \mathrm{acid} \mathrm{or}$ its analogue (Huang et al. 1993; Ali et al. 2011), which was one of the lignin-degraded products.

The different structural features among the treated and untreated lignin fractions were quantitatively investigated (Fig. 5(e) and (f)). The percentages of lignin side chains involved in the primary substructures A-C and the lignin units were calculated from the corresponding HSQC spectra (Wen et al. 2013). As expected, the main substructures present in all lignin fractions were the $\beta-O-4^{\prime}$ linked ones $\left(A, A^{\prime}\right.$, and $A^{\prime \prime}$ ), which ranged from $31.5 / 100 \mathrm{Ar}$ to $76.4 / 100 \mathrm{Ar}$. The $\beta-\beta^{\prime}$ resinol substructure (B) appeared to be the secondary major substructure, comprising 7.5/100 Ar to 18.0/100 Ar. The phenylcoumaran substructures (C) were calculated to be minor amounts, ranging from 1.9/100 Ar to 5.6/100 Ar. The content of $\beta-O-4^{\prime}$ aryl ether in MWL0 was 76.4/100Ar, and it decreased to 31.5/100 Ar in $\mathrm{MWL}_{4}$. These data suggested that the cleavage of the $\beta-O-4^{\prime}$ aryl ether (depolymerization) is the predominant reaction during bio-treatment. This might be because of the high activity of LiP in T. pubescens C7571, which attacks the $\beta-\mathrm{O}-4$ ' linkage of lignin (Umezawa et al. 1987). In addition to $\beta-\mathrm{O}-4^{\prime}$ aryl ether linkage cleavage and carboncarbon linkage degradation, the $\mathrm{S} / \mathrm{G}$ ratio in lignin was another prominent structural alteration observed after bio-treatment. The S, G, and $\mathrm{PB}$ ratios decreased from 53.1/100 Ar, 46.9/100 Ar, and
4.5/100 Ar to 23.0/100 Ar, 17.9/100 Ar, and 0.6/100 $\mathrm{Ar}$ for $\mathrm{MWL}_{0}$ and $\mathrm{MWL}_{4}$, respectively. Interestingly, the data also suggested that the G-type lignin was further degraded than the S-type, as revealed by a slightly elevated $\mathrm{S} / \mathrm{G}$ ratio in $\mathrm{MWL}_{0}$ (1.13) and $\mathrm{MWL}_{0}$ (1.29). Thus, G-type lignin was more easily degraded. Another possible reason is that the isolated MWL was mainly extracted from the middle lamella of the cell wall (Whiting and Goring 1982), which is more easily penetrated by the hyphae of white- rot fungi. Because G-type lignin has less methoxyl than S-type lignin, the cross-signals of methoxyls $(\delta \mathrm{C} / \delta \mathrm{H}$ $56.0 / 3.75)$ of $\mathrm{MWL}_{4}$ were stronger.

\section{Factors Influencing Biological Pre-treatment}

Biological pre-treatment is not only involved in generating any inhibitors and environmentally friendly methods, but also, it's a quietly time consuming method. To enhance it by choosing the most efficient strain and culture conditions can make the method more effective by decreasing the treatment time and carbohydrate loss. Important process factors affecting biological pre-treatment comprise the nature, component of biomass, and other factors such as variety of organisms engaged in incubation time and temperature, acidity $(\mathrm{pH})$, inoculums concentration, moisture content and aeration rate.

The optimum temperature during biological pretreatment varies with the type of microorganism employed. Most of the white rot ascomycetes fungi grow optimally around $39^{\circ} \mathrm{C}$ while the white rot basidiomycetes grow optimally around $25^{\circ} \mathrm{C}$ and $30^{\circ} \mathrm{C}$. The metabolism of these fungi generates heat and develops temperature gradients in solid state media. The accumulated heat can destroy or inhibit fungal growth and metabolism. Various optimal temperature for biological pre-treatment of biomass is because of fungal physiology, fungal strain and type of substrate. Incubation time requested for microorganisms pre-treatment differs depending on the strain and component of the biomass utilized for pre-treatment. Long incubation time due to low delignification rate is one of the major barriers for large scale application of biological pre-treatment.

Acidity $(\mathrm{pH})$ plays a prominent function in the cultivation of fungi and it is very complicated to 
control it in a solid culture condition. Production of lignolytic gene is influenced by the initial $\mathrm{pH}$ of the medium. In the $\mathrm{pH}$ of 4 to 5 most of the white rot fungi can grow

properly and also the substrate acidity decrease their growth. Inoculum concentration performs a significant function in biological pre-treatment. The time required for the colonization of the substrate is affected by the type and amount of inoculums. Spores are the commonly used inoculum. Larger quantity of inoculum leads to shorter time for colonization of the substrate.

High substrate concentrations have to be used for biological pre-treatment to make the process economically viable. Generation of inhibitor compounds increase by using high dry material that may unfavourably influence sugar yield reduction. Hence pre-treatment to be carried out with a compromised condition to minimize the generation as well as accumulation of inhibitory compounds. Initial moisture content is essential for the establishment of microbial growth in the biomass. Initial moisture content critically affects the fungal growth and enzyme production and significantly affects lignin degradation [63]. The production and $\mathrm{pH}$ of lignolytic enzymes mainly affected by aeration. Aeration has many functions which are including oxygenation, $\mathrm{CO}_{2}$ removal, heat dispersion, humidity conservation and also dispersal of volatile combinations produced during metabolism. Since lignin degradation is an oxidative process, oxygen availability is important for ligninase activity of white rot fungi. High aeration could improve delignification rate and hence controlled aeration is essential for improvement of biological pre-treatment. Efficiency of manganese peroxidase is not considerably influenced by aeration.

\section{Conclusion}

A surveying of the literature tells us that very little is known about the degradation of lignin in soil. Lignin is the most important and common aromatic organic compound found in the plant cell wall, and becomes a major source of humic acid in soil. Degraded lignin fragments are building blocks of the humic compounds in soil. Hence, lignin degradation has received vast attention from various researchers. The most efficient organisms for lignin mineralizing are white-rot fungi. Enzymes from specialized bacteria and fungi have been surveyed in this study that can metabolize lignin and enable utilization of ligninderived carbon as a resource. The study summarizes lignin biodegradation by various fungi and bacteria present in plant biomass and soils that are capable of producing ligninolytic enzymes such as LiP, MnP, VP, and DyP. Most of these enzymes are substrate specific, in contrast to Lac activity which oxidizes a variety of substrates like polyphenols, diphenols, benzenethiol and aromatic amines. Recent efforts to identify new lignin-degrading microbes and thorough study of their genomics, biochemistry, and proteomics will uncover the role of ligninolytic enzymes in the coming years.

\section{REFERENCES}

1. Adaskaveg, J.E., Gilbertson, R.L., Blanchette, R.A., 1990. Compar-ative studies of delignification caused by Ganoderma species. Appl. Environ. Microbiol. 56, 1932 1943.

2. Adaskaveg, J.E., Gilbertson, R.L., Dunlap, M.R., 1995. E ects of incubation time and temperature on in vitro selective delignificat-ion of silver leaf oak by Ganoderma colossum. Appl. Environ. Microbiol. 61, 138 \pm 144 .

3. Aiken, G.R., McKnight, D.M., Wershaw, R.L., MacCarthy, P., 1985. An introduction to humic substances in soil, sediment, and water. In: Aiken, G.R., McKnight, D.M., Wershaw, R.L., MacCarthy, P. (Eds.), Humic Substances in Soil, Sediment, and Water: Geochem-istry, Isolation, and Characterization, $1 \pm 9$. Wiley, USA.

4. Albertsson, A.C., Karlsson, S., 1995. Degradable polymers for the future. Acta Polymer 46, $114 \pm 123$.

5. Almendros, G., Gonzalez-Vila, F.J., Martin, F., Frund, R., Ludemann,

6. H.D., 1992. Solid state NMR studies of fireinduced changes in the structure of humic substances. Sci. Total Environ. 117/118, 63 \pm 74 .

7. Argyropoulos, D.S., Menachem, S.B., 1997. Lignin. In: Eriksson, K.-E.L. (Ed.), Advances in Biochemical Engineering Biotechnol-ogy, vol. 57. Springer, Germany, pp. $127 \pm 158$.

8. Atkinson, C.F., Jones, D.D., Gauthier, J.J., 1996a. Biodegradabilities and microbial activities during composting of oxidation ditch sludge. Compost. Sci. Utiliz. 4, 84 \pm 96 . 
9. Atkinson, C.F., Jones, D.D., Gauthier, J.J., 1996b. Putative anaerobic activity in aerated composts. J. Ind. Microbiol. 16, 182 \pm 188 .

10. Baca, M.T., Fornasier, F., de Nobili, M., 1992. Mineralization and humification pathways in two composting processes applied to cotton wastes. J. Ferment. Bioeng. 74, 179 \pm 184 .

11. Ball, A.S., Betts, W.B., McCarthy, A.J., 1989. Degradation of lignin-related compounds by actinomycetes. Appl. Environ. Microbiol. 55, $1642 \pm 1644$.

12. Be a, T., Blanc, M., Lyon, P.F., Vogt, G., Marchiani, M., Fischer, J.L., Aragano, M., 1996. Isolation of Thermus strains from hot composts $60 \pm 80^{\circ} \mathrm{C}$. Appl. Environ. Microbiol. 62, $1723 \pm 1727$.

13. Benner, R., Hodson, R.E., 1985. Thermophilic anaerobic biodegrada-tion of $\left[{ }^{14} \mathrm{C}\right]$ ignin, $\left[{ }^{14} \mathrm{C}\right]$ cellulose, and $\left[{ }^{14} \mathrm{C}\right]$ lignocellulose preparations. Appl. Environ. Microbiol. 50, 971 \pm 976.

14. Biermann, C.J., 1993. Essentials of Pulping and Papermaking. Academic Press, USA.

15. Blanchette, R.A., 1995. Degradation ti of lignocellulose complex in wood. Can. J. Bot. 73, $\mathrm{S} 999 \pm \mathrm{S} 1010$.

16. Brock, T.D., $1978 . \quad$ Thermophilic Microorganisms and Life at High Temperatures. Springer, USA.

17. Brown, A., 1985. Review of lignin in biomass. J. Appl. Biochem. 7, 371 \pm 387 .

18. Buswell, J.A., Odier, E., 1987. Lignin biodegradation. CRC Crit. Rev.

19. Biotechnol. $6,1 \pm 60$.

20. Chandler, J.A., Jewell, W.J., Gossett, J.M., Soest, P.J., Robertson, J.B., 1980. Predicting methane fermentation biodegradability. Biotechnology and Bioengineering Symposium 10, 93 \pm 107 .

21. Chang, Y., 1967. The fungi of wheat straw compost. II Biochemical and physiological studies.. Trans. Br. Mycol. Soc. 50, 667 \pm 677.

22. Chen, Y., Chefetz, B., Hadar, Y., 1996. Formation and properties of humic substance originating from compost. In: Bertoldi, M., Sequi, P., Lemmes, B., Papi, T. (Eds.), European Commission Interna-tional Symposium. The Science of Composting, 382 \pm 393 . Blackie Academic \& Professional, England.

23. Colberg, P.J., 1988. Anaerobic microbial degradation of cellulose, lignin, oligolignols, and monoaromatic lignin derivates. In: Zehnder,
A.J.B. (Ed.), Biology of Anaerobic Microorganisms, $333 \pm 372$. Wiley, USA.

24. Cooney, D.G., Emerson, R., 1964. Thermophilic Fungi. W.H. Freeman, USA.

25. Crawford, D.L., Crawford, R.L., 1980. Microbial degradation of lignin. Enzyme Microb. Technol. $2,11 \pm 22$.

26. Crawford, R.L., Robinson, L.E., Cheh, A.M., 1980. ${ }^{14}$ C-labeled lignins as substrates for the study of lignin biodegradation and transformation. In: Kirk, T.K., Higuchi, T., Chang, H.m. (Eds.), Lignin Biodegradation: Microbiology Chemistry and Applications. CRC

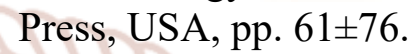

27. Crawford, J.H., 1983. Composting of agricultural wastes \pm a review.

28. Process Biochem. 18, 14 \pm 18 .

29. Crisan, E.V., 1973. Current concepts of thermophilism and the thermophilic fungi. Mycologia 65, 1171 \pm 1198 .

30. Cross, T., 1968. Thermophilic actinomycetes. J. Appl. Bact. 31, 36 \pm 53 .

31. Dence, C.W., 1992. The determination of lignin. In: Lin, S.Y., Dence, C.W. (Eds.), Methods in Lignin Chemistry, $33 \pm 61$. Springer, Berlin.

32. Dix, N.J., Webster, J., 1995. Fungal Ecology. Chapman \& Hall, Cambridge, Great Britain.

33. Eggins, H.O.W., Malik, K.A., 1969. The occurrence of thermophilic cellulolytic fungi in a pasture land soil. Antonie v. Leeuwenhoek 35, $178 \pm 184$.

34. El-Naghy, M.A., El-Katatny, M.S., Attia, A.A., 1991. Degradation of cellulosic materials by Sporotrichum thermophile culture filtrate for sugar production. Int. Biodeter. 27, 75 \pm 86 .

35. Eriksson, K.-E.L., Blanchette, R.A., Ander, P., 1990. Microbial and Enzymatic Degradation of Wood and Wood Components. Spring-er, Berlin, Germany.

36. European Standard CEN TC261, SC4, WG2, draft 1998. Require-ments for packaging recoverable in the form of composting and biodegradation. Test scheme and evaluation criteria for the final acceptance of packaging.

37. European Union Packaging and Packaging Waste Directive, 1994. European parliament and council directive 94/62/EC of 20 December 1994 on packaging and packaging waste.

38. Faure, D., Deschamps, A.M., 1990. Physicochemical and microbio-logical aspects in 
composting of grape pulps. Biol. Wastes 34, $251 \pm 258$.

39. Fergus, C.L., 1964. Thermophilic and thermotolerant molds and actinomycetes of mushroom compost during peak heating. Mycologia $56,267 \pm 284$.

40. Fergus, C.L., 1969. The cellulolytic activity of thermophilic fungi and actinomycetes. Mycologia $61,120 \pm 129$.

41. Forssell, P., Mikkila, J., Suortti, T., Seppala, J., Poutanen, K., 1996. Plasticization of barley starch with glycerol and water. J. Macro-mol. Pure Appl. Chem. A33, $703 \pm 715$.

42. Franzluebbers, A.J., Arshad, M.A., Ripmeester, J.A., 1996. Altera-tions in canola residue composition during decomposition. Soil Biol. Biochem. 28, 1289 \pm 1295 .

43. Fustec, E., Chauvet, E., Gas, G., 1989. Lignin degradation and humus formation in alluvial soils and sediments. Appl. Environ. Micro-biol. 55, $922 \pm 926$.

44. Goddard, R. 1997. Packaging 2004. Pira International.

45. Godden, B., Ball, A.S., Helvenstein, P., McCarthy, A.J., Penninckx, M.J., 1992. Towards elucidation of the lignin degradation pathway in actinomycetes. J. Gen. Microbiol. 138, $2441 \pm 2448$.

46. Golueke, C.G., 1991. Principles of composting. In: The Sta of BioCycle Journal of Waste Recycling. The Art and Science of Composting. The JG Press Inc., Pennsylvania, USA, pp. $14 \pm 27$.

47. Golueke, C.G., 1992. Bacteriology of composting. BioCycle 33, 55 \pm 57 .

48. Hackett, W.F., Connors, W.J., Kirk, T.K., Zeikus, J.G., 1977.

49. Microbial decomposition of synthetic ${ }^{14} \mathrm{C}$-labeled lignins in nature: Lignin biodegradation in a variety of natural materials. Appl. Environ. Microbiol. 33, 43 \pm 51 .

50. Haider, K., Martin, J.P., Rietz, E., 1977. Decomposition in soil of ${ }^{14} \mathrm{C}$-labeled coumaryl alcohols; free and linked into dehydropolymer and plant lignins and model humic acids. Soil Sci. Soc. Am. J. 41, 556 \pm 562.

51. Haider, K., Trojanowski, J., 1980. A comparison of the degradation of ${ }^{14} \mathrm{C}$-labeled DHP and corn stalk lignins by micro-and macrofungi and bacteria. In: Kirk, T.K., Higuchi, T., Chang, H.m.
(Eds.), Lignin Biodegradation: Microbiology, Chemistry and Applica-tions, vol. 1. CRC Press Inc., USA, pp. $111 \pm 134$.

52. Hatakka, A.I., Pirhonen, T.I., UusiRauva, A.K., 1984. Decomposition of ${ }^{14} \mathrm{C}$-lignins by white-rot fungi. In: Materials of Soviet-Finland Seminar on Bioconversion of Plant Raw Materials by Microor-ganisms $\quad 5 \pm 10 \quad$ December 1983, Tashkent, Scientific Center of Biological Research of the Academy of Sciences of the USSR in Pushchino, Pushchino, pp. 102 \pm 110.

53. Hatakka, A., 1994. Lignin-modifying enzymes from selected white-rot fungi: production and role in lignin degradation. FEMS Microbiol. Rev. $13,125 \pm 135$.

54. Haug, R.T., 1993. The Practical Handbook of Compost Engineering.

55. Lewis Publishers, Boca Raton, USA.

56. Horwath, W.R., Elliott, L.F., 1996. Ryegrass straw component decomposition during mesophilic and thermophilic incubations. Biol. Fertil. Soils 21, 227 \pm 232 .

57. Inbar, Y., Chen, Y., Hadar, Y., 1989. Solid-state carbon-13 nuclear magnetic resonance and infrared lispectroscopy of composted organic matter. Soil. Sci. Am. J. 53, 1695 \pm 1701.

58. Inbar, Y., Chen, Y., Hadar, Y., Hoitink, H.A.J., 1990. New approaches to compost maturity. BioCycle 31, 64 \pm 69 .

59. Itavaara, M., Venelampi, O., Karjomaa, S., 1995. Testing methods for determining the compostability of packaging materials. In: Barth, J. (Ed.), Proceedings of Biological Waste Management "Wasted Chance". BWM Infoservice, Germany.

60. Itavaara, M., Vikman, M., Venelampi, O., 1997. Windrow composting of biodegradable

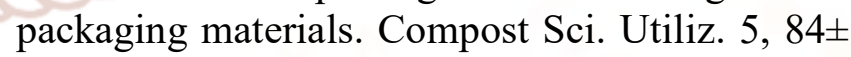
92.

61. Kane, B.E., Mullins, J.T., 1973. Thermophilic fungi in a municipal waste compost system. Mycologia 65, 1087 \pm 1100 .

62. Kirk, T.K., Farrell, R.L., 1987. Enzymatic combustion: the microbial degradation of lignin. Ann. Rev. Microbiol. 41, 465 \pm 505.

63. Kuhad, R.C., Singh, A., Eriksson, K.E.L., 1997. Microorganisms and enzymes involved in the degradation of plant fiber cell walls. In: Eriksson, K.E.L. (Ed.), Advances in Biochemical 
Engineering/ Biotechnology, vol. 57. Springer, Germany, pp. $46 \pm 125$.

64. Leppanen-Turkula, A. 1999. Association of Packaging Technology and Research. Personal communication.

65. Lin, S.Y., Dence, C.W. (Eds.), 1992. Methods in Lignin Chemistry. Springer, Berlin.

66. Machuca, A., Duran, N., 1996. Optimization of some parameters in uencing Thermoascus aurantiacus growth: e ects of lignin-related compounds. J. Ind. Microbiol. 16, 224 \pm 229.

67. Machuca, A., Milagres, A.M.F., Aoyama, H., Duran, N. 1995. Extracellular component with high phenoloxidase activity from Thermoascus aurantiacus: potentials in pulp and paper applications. Proc. of the 4th Brazilian Symposium on the Chemistry of Lignins and Other Wood Components. Technology Centre, Fed-eral University of Pernabuco, Recife, PE, Brazil, 28 November \pm 1 December 1995.

68. Maheshwari, R., Kamalam, P.T., 1985. Isolation and culture of thermophilic fungus Melanocarpus albomyces, and factors in u-encing the production and activity of xylanase. J. Gen. Microbiol. 131, 3017 \pm 3027 .

69. Martin, J.P., Haider, K. 1980. Microbial degradation and stabilization of ${ }^{14} \mathrm{C}$-labeled lignins, phenols, and phenolic polymers in relation to soil humus formation. In: Kirk, T.K., Higuchi, T., Chang, H.m. (Eds.), Lignin Biodegradation: Microbiology, Chemistry and Applications, vol. 1. CRC Press, USA, pp. $77 \pm 100$.

70. McKinley, V.L., Vestal, J.R., 1985. Physical and chemical correlates of microbial activity and biomass in composting municipal sewage sludge. Appl. Environ. Microbiol. 50, 1395 \pm 1403.

71. Micales, J.A., Skog, K.E., 1997. The decomposition of forest products in landfills. Int. Biodeter. Biodegrad. 39, 145 \pm 158 .

72. Mouchacca, J., 1997. Thermophilic fungi: Biodiversity and taxonomic status. Cryptogamie Mycol. 18, $19 \pm 69$.

73. Nakasaki, K., Sasaki, M., Shoda, M., Kubota, H., 1985. Characteristic of mesophilic bacteria isolates isolated during thermophilic com-posting of sewage sludge. Appl. Environ. Microbiol. 49, $42 \pm 45$.

74. Nusbaumer, C., Job, D., Aragno, M., 1996. Etude de 1Õalteration par les champignons de lÕetat physico-chimique des composes lignocellulosiques dans un processus naturel de compostage. Mycologia Helvetica 8, 51 \pm 67 .

75. Ofosu-Asiedu, A., Smith, R.S., 1973. Some factors a ecting wood degradation by thermophilic and thermotolerant fungi. Mycologia 65, 87 \pm 98 .

76. Paatero, J., Lehtokari, M., Kemppainen, E. 1984. Kompostointi. WSOY, Juva (in Finnish).

77. Pagga, U., 1999. Compostable packaging materials \pm test methods and limit values for biodegradation. Appl. Microbiol. Biotechnol. 51, $125 \pm 133$.

78. Rayner, A.D.M., Boddy, L., 1988. Fungal Decomposition of Wood. Wiley, Great Britain.

79. Ri aldi, R., Levi-Minzi, R., Pera, A., de Bertoldi, M., 1986. Evalu-ation of compost maturity by means of chemical and microbial analysis. Waste Manag. Res. 4, 387 \pm 396 .

80. Robinson, C.H., Dighton, J., Frankland, J.C., Roberts, J.D., 1994. Fungal communities on decaying wheat straw of di erent resource qualities. Soil Biol. Biochem. 26, $1053 \pm 1058$.

81. Rodriguez, A., Perestelo, F., Carnicero, A., Regalado, V., Perez, R., De la Fuente, G., Falcon, M.A., 1996. Degradation of natural lignins and lignocellulosic substrates by soil-inhabiting fungi imperfecti. FEMS Microbiol. Ecol. 21, 213 \pm 219 .

82. Romanelli, R.A., Houston, C.W., Barnett, S.M., 1975. Studies on thermophilic cellulolytic fungi. Appl. Microbiol. 30, 276 \pm 281 .

83. Rosenberg, S.L., 1975. Temperature and $\mathrm{pH}$ optima for 21 species of thermophilic and thermotolerant fungi. Can. J. Microbiol. 21, $1535 \pm 1540$.

84. Rosenberg, S.L., 1978. Cellulose and lignocellulose degradation by thermophilic and thermotolerant fungi. Mycologia 70, 1 13 .

85. Ruttimann, C., Vicuna, R., Mozuch, M.D., Kirk, T.K., 1991. Limited bacterial mineralization of fungal degradation intermediates from synthetic lignin. Appl. Environ. Microbiol. 57, 3652 \pm 3655.

86. Sharma, H.S.S., 1989. Economic importance of thermophilous fungi. Appl. Microbiol. Biotechnol. 31, $1 \pm 10$.

87. Sjostrom, E., 1993. Wood Chemistry, Fundamentals and Applications, 2nd ed. Academic Press, New York/London.

88. Srinivasan, C., DÕSouza, T.M., Boominathan, K., Reddy, C.A., 1995. Demonstration of laccase 
in the white rot basidiomycete Phaner-ochaete chrysosporium BKM-F1767. Appl. Environ. Microbiol. 61, 4274 \pm 4277 .

89. Straatsma, G., Samson, R.A., Olijnsma, T.W., Op den Camp, H.J.M., Gerrits, J.P.G., van Griensven, L.J.L.D., 1994. Ecology of thermophilic fungi in mushroom compost, with emphasis on Scytalidium thermophilum and growth stimulation of Agaricus bisporus mycelium. Appl. Environ. Microbiol. 60, $454 \pm 458$.

90. Strom, P.F., 1985a. E ect of temperature on bacterial species diversity in thermophilic solidwaste composting. Appl. Environ. Microbiol. 50, $899 \pm 905$.

91. Strom, P.F., 1985b. Identification of thermophilic bacteria in solid-waste composting. Appl. Environ. Microbiol. 50, 907 \pm 913 .

92. Stutzenberger, F.J., Kaufman, A.J., Lossin, R.D., 1970. Cellulolytic activity in municipal solid waste composting. Can. J. Microbiol. 16, $553 \pm 560$.

93. Thambirajah, J.J., Kuthubutheen, A.J., 1989. Composting of palm press fibre. Biol. Wastes 27, $257 \pm 269$.

94. Thambirajah, J.J., Zukali, M.D., Hashim, M.A., 1995. Microbiological and biochemical changes during composting of palm empty-fruit-bunches. $E$ ect of nitrogen supplementation on the substrate. Bioresource Technol. 52, 133 \pm 144 .

95. Tomati, U., Galli, E., Pasetti, L., Volterra, E., 1995. Bioremediation of olive-mill wastewaters

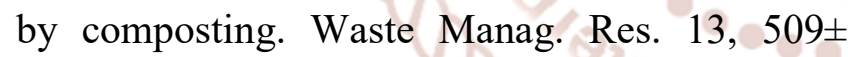
518.

96. Tseng, D.Y., Vir, R., Traina, S.J., Chalmers, J.J., 1996. A Fourier-trasform infrared spectroscopic analysis of organic matter degradation in a bench-scale solid substrate fermentation composting system. Biotechnol. Bioeng. 52, $661 \pm 671$.

97. Varadachari, V., Ghosh, K., 1984. On humus formation. Plant Soil 77, 305 \pm 313 .

98. Vicuna, R., 1988. Bacterial degradation of lignin. Enzyme Microb.Technol. 10, 646 655 .

99. Klopotek, A., 1962. Uber das Vorkommen und Verhalten von Schimmelpilzen bei der Kompostierung Stadtischer Abfallsto e. Antonie v. Leeuwenhoek 28, 141 160 .

100. Waksman, S.A., Umbreit, W.W., Cordon, T.C., 1939a. Thermophilic actinomycetes and

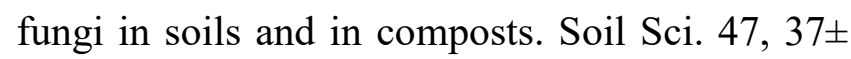
61.

101. Waksman, S.A., Cordon, T.C., Hulpoi, N., 1939b. Influence of temperature upon the microbiological population and decom-position processes in composts of stable manure. Soil Sci. $47,83 \pm 114$.

102. Wen, J. L., Yuan, T. Q., Sun, S. L., Xu, F., and Sun, R. C. (2013). "Understanding the chemical transformations of lignin during ionic liquid pretreatment," Green Chem. 16(1), 181190. DOI: $10.1039 / \mathrm{c} 3 \mathrm{gc} 41752 \mathrm{~b}$

103. Wen, J. L., Sun, S. L., Yuan, T. Q., and Sun, R. C. (2014). "Structural elucidation of whole lignin from Eucalyptus based on preswelling and enzymatic hydrolysis," Green Chem. 17(3),15891596. DOI: $10.1039 / \mathrm{c} 4 \mathrm{gc} 01889 \mathrm{c}$

104. Whiting, P., and Goring, D. A. I. (1982). "Chemical characterization of tissue fractions from the middle lamella and secondary wall of black spruce tracheids," Wood Sci. Technol. 16(4), 261-267. DOI: 10.1007/BF00353149

105. J Wörmeyer, K., Ingram, T., Saake, B., Brunner, G., and Smirnova, I. (2011). "Comparison of different pretreatment methods for lignocellulosic materials. Part II: Influence of pretreatment on the properties of rye straw lignin," Bioresource Technol. 102(5), 4157-4164. DOI: $10.1016 /$ j.biortech.2010.11.063

106. Yelle, D. J., Wei, D., Ralph, J., and Hammel, K. E. (2011). "Multidimensional NMR analysis reveals truncated lignin structures in wood decayed by the brown rot basidiomycete Postia placenta," Environ. Microbiol. 13(4), 1091-1100. DOI: $10.1111 / j .1462-2920.2010 .02417 . x$

107. Zadrazil, F. (1985). "Screening of fungi for lignin decomposition and conversion of straw into feed," Angew. Bot. 59, 252-433. DOI: 10.1007/BF02826558

108. Zhao, Q., and Dixon, R. A. (2011). "Transcriptional networks for lignin biosynthesis: More complex than we thought," Trends Plant $\begin{array}{lll}\text { Sci. } & 16(4), \quad 227-233 . & \text { DOI: }\end{array}$ 10.1016/j.tplants.2010.12.005 